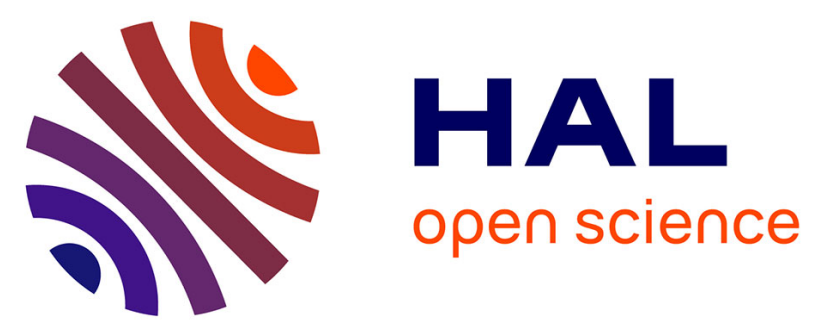

\title{
Structural inheritance in the Central Pyrenees: the Variscan to Alpine tectonometamorphic evolution of the Axial Zone
}

Bryan Cochelin, Baptiste Lemirre, Yoann Denèle, Michel de Saint Blanquat, Abdeltif Lahfid, Stéphanie Duchêne

\section{To cite this version:}

Bryan Cochelin, Baptiste Lemirre, Yoann Denèle, Michel de Saint Blanquat, Abdeltif Lahfid, et al.. Structural inheritance in the Central Pyrenees: the Variscan to Alpine tectonometamorphic evolution of the Axial Zone. Journal of the Geological Society, 2018, 175 (2), pp.336 - 351. 10.1144/jgs2017-066 . hal-01761295

\section{HAL Id: hal-01761295 \\ https://hal.science/hal-01761295}

Submitted on 13 Jul 2019

HAL is a multi-disciplinary open access archive for the deposit and dissemination of scientific research documents, whether they are published or not. The documents may come from teaching and research institutions in France or abroad, or from public or private research centers.
L'archive ouverte pluridisciplinaire HAL, est destinée au dépôt et à la diffusion de documents scientifiques de niveau recherche, publiés ou non, émanant des établissements d'enseignement et de recherche français ou étrangers, des laboratoires publics ou privés. 
1 Structural inheritance in the Central Pyrenees: The Variscan to Alpine tectono- metamorphic

2 evolution of the Axial Zone

3

4 Bryan COCHELIN ${ }^{\mathrm{a}, \mathrm{b}} *$, Baptiste LEMIRRE $^{\mathrm{a}}$, Yoann DENELE ${ }^{\mathrm{a}}$, Michel de SAINT

5 BLANQUAT $^{\mathrm{a}}$, Abdeltif LAHFID ${ }^{\mathrm{b}}$, Stéphanie DUCHENE ${ }^{\mathrm{a}}$

6

7

8 a Géosciences Environnement Toulouse, Université de Toulouse, CNRS, IRD, UPS, CNES, F-

931400 , France

$10{ }^{\mathrm{b}}$ BRGM, 3 avenue Claude Guillemin, F-45060 Orléans, France

11

$12 *$ corresponding author: bryan.cochelin.get@ gmail.com

13

14

15

Submitted to Journal of the Geological Society, 24 May 2017

16

Revised, 05 September 2017

17 


\section{Abstract}

Estimating structural inheritance in orogens is critical to understand the manner in which plate convergence is accomodated. The Pyrenean belt, which developed in Late Cretaceous to Paleogene times, was affected by Cretaceous rifting and Variscan orogeny. Here we combine a structural and petrological study of the Axial Zone in the Central Pyrenees to discuss structural inheritance. Low-grade Paleozoic metasedimentary rocks were affected by a Variscan transpressional event that produced successively: (i) regional-scale folds; (ii) isoclinal folding, steep pervasive cleavage and vertical stretching, synchronous with peak metamorphism; (iii) and strain localization into ductile reverse shear zones. The persistence of a relative flat envelop for the Paleozoic sedimentary pile and Variscan isograds, and the absence of Alpine crustal-scale faults in the core of the Axial Zone, suggest that the Axial Zone constitutes a large Variscan structural unit preserved during Pyrenean orogeny. This configuration seems to be inherited from

Cretaceous rifting, which led to the individualization of a large continental block (future Axial Zone) against a hyper-extended domain along the North Pyrenean Fault zone. This study places the currently prevailing model of Pyrenean belt deformation in a new perspective and bears important implications for crustal evolution and inheritance in mountain belts more generally.

Keywords: Structural inheritance, Pyrenean belt, Variscan orogeny, Passive margin inversion, Central Pyrenees, RSCM thermometry

\section{Supplementary materials:}

- Table with RSCM data. - Figure illustrating peak-fitting of the Raman spectrum of carbonaceous material and Raman spectra from the various samples of the Pallaresa cross-section 
The crustal architecture of a mountain belt narrowly depends on the rheology and relative thickness of the continental plates involved in the collision. If the two plates were passive margins, both were affected by rifting before convergence, leading to variably thinned domains of continental crust, dismembered by normal faults or detachments. At the initiation of convergence, the thickness and structure of the two margins exert first-order controls on the architecture of the mountain belt (Mouthereau \& Lacombe, 2006; Wrobel-Daveau et al., 2010; Mohn et al., 2012; Mouthereau et al., 2012; McIntosh et al., 2013; Masini et al., 2014; Bellahsen et al., 2014). The thinnest and thermally weaker continental margin is preferentially affected by shortening during inversion of the rift systems and favourably orientated structures, which are inherited from rifting, could be reactivated (Beaumont et al., 2000; Masini et al., 2011; Mouthereau et al., 2012, 2013; Mesalles et al., 2014; Vacherat et al., 2014). At the paroxysm of collision, when the two margins are accreted into the orogenic prism, new thrusts (unrelated to the rift) are generated to balance shortening, and pre-rift structures within the basement may undergo reactivation (Cloke et al., 1997; Allen et al., 1998; Soulaimani \& Burkhard, 2008). However, the importance of these long-term inherited structures is most of the time overlooked because of the polyphase tectonic history or because of the absence of structural markers to constrain it.

The importance of rift-related structures has been previously illustrated in the Pyrenees (Choukroune, 1992), where the European and Iberian plates began to collide in Late Cretaceous times (Dubois \& Seguin, 1978; Roest \& Srivastava, 1991; Olivet, 1996). Early Cretaceous rifting led to the formation of an ultra-thinned northern margin and to the exhumation of subcontinental mantle (Lagabrielle and Bodinier, 2008; Lagabrielle et al., 2010; Masini et al., 2014; Clerc \& Lagabrielle, 2014; de Saint Blanquat et al., 2016; Vacherat et al., 2016). While the European margin was hyper-extended in Cretaceous times, no evidence of this type of extension has been detected in the Iberian plate, i.e. in the hinterland and in the southern foreland of the Pyrenean 
belt. This hinterland, which corresponds to the so-called Axial Zone, is mainly made of Paleozoic metasediments and magmatic bodies involved in the Variscan orogeny (Fig. 1a \& 1b). Deep exhumation of the Axial Zone is responsible for the erosion of post-Variscan deposits, which form the main structural marker of the Cretaceous rifting event and Pyrenean collision. Since the ECORS deep seismic profile (Roure et al., 1989; Choukroune, 1989; Choukroune et al., 1990), the Pyrenees were interpreted as an asymmetric, doubly vergent collisional wedge with numerous stacked crustal units in the Axial Zone (Fig. 1c). Whereas this geometry is in agreement with structural observations made in the Central to Western Pyrenees, where the crustal-scale north-dipping Gavarnie and Les Eaux Chaudes/Lakhora thrusts are observed (Fig. 1b), the continuity of these structures in the Central and Eastern Pyrenees has remained debated (Carreras and Debat, 1996; Soler et al. 1998; Laumonier, 2015). Moreover, the anticlinal nappestack model developed by Muñoz (1992) implies that the Variscan crust of the Central Pyrenees was deeply affected by both Cretaceous rifting and Alpine orogeny, implying large-scale bloc rotations, internal deformation and thrusting (Berastegui et al., 1993; Beaumont et al., 2000; Mouthereau et al., 2014). Nevertheless, detailed structural studies performed at local scale on the Variscan crust in the last 20 years tend to indicate only limited reactivation of Variscan structures (Bons, 1988; Carreras \& Debat, 1996; Capella and Carreras, 1996; Soler et al., 1998; Mezger \& Passchier, 2003; Denèle et al. 2008; Clariana \& García-Sansegundo, 2009; Laumonier, 2015). In order to resolve this apparent paradox, we try here to better constrain the deformation of the Central Pyrenees through time. We combine a structural, petrological and geothermometric study of the Variscan crust along the ECORS seismic profile. This study allows us to discuss the structure of the hinterland of the central Pyrenean belt and the relative impact of structures inherited from the Lower Cretaceous rifting event and from the Variscan orogeny. We also propose a new model of the eastern Pyrenean crustal wedge in which a pop-up structure corresponding to the Axial Zone was thrusted over the southern foreland along moderately 
dipping ramps. This constitutes an alternative view by comparison to the currently prevailing model (Muñoz et al., 1992), which advocates severals steeply-dipping thrusts cross-cutting the Axial Zone.

\section{Geological setting}

The Axial Zone of the Pyrenean range is classically described as being affected by thickskinned tectonics involving several basement thrust sheets (Fig. 1c), namely the Lakhora, Gavarnie and Bielsa units in the western part (Teixell et al., 1998), and the Nogueres, Orri, and Rialp units in the east (e.g. Vergés et al., 1995). The crustal-scale, north-dipping Gavarnie and Les Eaux Chaudes/Lakhora thrusts that placed basement rocks over Cretaceous cover constitute a major feature of the Pyrenean range and have been studied in detail. In the field, these two thrusts form hundred metre-thick high-strain zones, mainly consisting of brittle-ductile mylonites and breccia (Déramond, 1979; Majesté-Menjoulas, 1979). The Nogueres unit (Fig. 1c) is defined in the northern part of the Axial Zone (Muñoz, 1992) as the rooting zone of the socalled "têtes plongeantes" or "plunging noses" defined to the south of the Axial Zone, that consists of overturned synforms of Devonian to Permo-Triassic series (Vergely, 1970; Séguret, 1972; Choukroune \& Séguret, 1973). This basement sheet is interpreted as the lateral continuity of the Gavarnie unit separated from the Orri unit to the south by the Gavarnie thrust (Beaumont et al., 2000; Mouthereau et al., 2014). While this thrust is clearly identified in the western Axial Zone (Majesté-Menjoulas, 1979), its lateral continuity in the Central Pyrenees is discussed, as this zone is devoid of post-Variscan deposits to identified Pyrenean thrusting, except one outcrop of Triassic deposits, deformed in a fault zone located north on the Maladeta massif (Fig. 2 \& 3, see Soler et al., 1998).

The Axial Zone consists of Precambrian and Paleozoic rocks that were affected by the Variscan orogeny between $330 \mathrm{Ma}$ and $290 \mathrm{Ma}$ (Denèle et al., 2014 and references therein). The 
116 Variscan orogeny is marked by Permo-Carboniferous deformation, high temperature-low

117 pressure (HT-LP) regional metamorphism, and calc-alkaline plutonism. The Variscan crust of 118 the Axial Zone is classically interpreted as being formed by two contrasting structural levels (de 119 Sitter \& Zwart, 1962; Carreras \& Capella, 1994): (i) an upper crustal level, also called

120 "Superstructure", made of low-grade metamorphosed Paleozoic sediments and defined by tight

121 to upright folds and steep axial-plane cleavage; (ii) a lower crustal level, or "Infrastructure", 122 mostly characterized by Precambrian to Lower Paleozoic rocks affected by HT-LP 123 metamorphism and exposed into domal structures with shallow-dipping foliation planes. Recent 124 studies suggest that the formation of these two domains was coeval and occurred in a dextral 125 transpressive regime (Gleizes et al., 1998b; Mezger, 2009; Denèle et al., 2014). In the Central Pyrenees, rocks affected by the Variscan orogeny are made of Cambrian 127 to Carboniferous metasedimentary rocks (Fig. 2). Cambrian to Ordovician rocks occupy the 128 central part of two regional-scale antiforms, the Pallaresa and Orri anticlines (Fig. 2). Whereas 129 the stratigraphy of Cambrian to Lower Ordovician rocks remains poorly constrained because of 130 its azoic character, the stratigraphic continuity between Upper Ordovician conglomerates and 131 lower series in the southern flank of the Pallaresa anticline seems to confirm that the older rocks 132 occupy the core of the anticline (Zandvliet, 1960; Hartevelt, 1970; Laumonier et al., 1996). The 133 lower terms are made of sandstone, locally microconglomerate and limestone at the top, 134 described as belonging to the Cambrian Evol Formation (Laumonier et al., 1996). The upper 135 series, belonging to the Cambrian Jujols Formation (Laumonier et al., 1996), is mainly made of 136 sandstone and greenish to dark schist. The upper Paleozoic series outcrops occur in the Couflens 137 syncline, bording the North Pyrenean Fault, and in the Llavorsi syncline, pinched between the 138 Pallaresa and Orri anticlines (Fig. 2). These Upper Paleozoic rocks are made of (i) thin levels of 139 Silurian black shale and limestone; (ii) a succession of Devonian sandstone, limestone and schist 
140 with significant local variations of facies (see García-Sansegundo et al., 2011 and references

141 therein); and (iii) Middle Carboniferous flysch.

The Cambrian to Paleozoic metasedimentary rocks of the Central Pyrenees are affected

143 by multi-scale folds and pervasive axial-plane cleavage, developed under low-grade

144 metamorphic conditions (Zwart, 1979; Bons, 1988; Capella and Carreras, 1996). The Paleozoic

145 metasedimentary rocks of the Superstructure are intruded by voluminous calc-alkaline plutons

146 such as the Maladeta pluton in the west, the Bassiès, Marimanha and Ribérot plutons in the north,

147 with U/Pb ages ranging between 312 and $298 \mathrm{Ma}$ (Evans, 1993; Paquette et al., 1997; Denèle et

148 al., 2014). The intrusion of these plutons is considered as coeval with the late Carboniferous

149 dextral transpressional event (Bouchez \& Gleizes, 1995; Evans et al., 1997; Gleizes et al.,

150 1998a). The Infrastructure marked by HT-LP metamorphic rocks and flat-lying foliations can be

151 observed in the Aston gneiss dome directly to the east of the Pallaresa anticline (Fig. 2) (Mezger,

152 2009; Denèle et al., 2009).

153 The central part of the Axial Zone is cut by several shear zones and faults generally

154 considered as Variscan in age, with reactivation during the Pyrenean collision. However, no real

155 consensus exists about the age and relative importance of activation and reactivation of these

156 various faults (Figs. $2 \& 3$ ). The older one is the Port de Salau fault, an east-west steeply north-

157 dipping fault. In its current position, its footwall consists of Cambrian rocks belonging to the

158 Pallaresa anticline, and its hangingwall of Siluro-Devonian rocks (Fig. 2). This fault seems to be

159 folded by the late Variscan transpressional event, and is interpreted by some authors as an early

160 Variscan thrust with a probable southward displacement (Bodin and Ledru, 1986; Losantos et

161 al., 1986). Farther south the Lladorre shear zone, localized in Cambrian limestones, is considered

162 by Capella \& Carreras (1996) as a late reverse Variscan shear zone. This shear zone constitutes

163 the western continuity of the Variscan kilometre-scale Mérens shear zone (Fig. 2), which was

164 reactivated during the Alpine orogeny as a localized fault (McCaig, 1986; Denèle et al., 2008; 
Mezger et al., 2012). Other authors (Berastegui et al., 1993; Beaumont et al., 2000; Vissers \&

166

Meijer, 2012) consider this shear zone as an Alpine thrust that could be a hypothetical candidate for the lateral continuity of the Gavarnie thrust, and renamed it the Pallaresa thrust. It is supposed to be responsible for the stacking of the Nogueres sheet over the Orri sheet, with a proposed displacement around 15-20 km. Farther south, the Estarón thrust was considered by Casas et al., (1989) to represent a Variscan thrust, while other authors consider it as another candidate for the continuity to the east of the main Alpine Gavarnie thrust (Metcalf et al., 2009; Mouthereau et al., 2014). Similarly, the Llavorsi thrust is considered to be a Variscan thrust in some studies (Casas et al., 1989; Clariana, 2001), but an Alpine thrust belonging to the Orri sheet in others studies (Zwart, 1986; Vergés et al., 1995, 2002). Its subtractive character, placing Devonian over Cambro-Ordovician rocks, has led some authors to consider it as a normal fault, either Early Carboniferous (Capellà \& Bou, 1997), or Late Carboniferous to Cretaceous in age (Casas et al., 2007). Further south, the Orri and Nogueres thrusts are indisputably Alpine in age, putting Paleozoic rocks on Permian to Triassic sediments (Fig. 2). The Orri thrust accommodated 10-15 km of displacement during the collision (Séguret, 1972; Berastegui et al., 1993; Beaumont et al., 2000; Mouthereau et al., 2014) and is supposed to be a reactivated Cretaceous normal fault (Berastegui et al., 1993; Beaumont et al., 2000).

Discussion about the age of shear zones and faults in the Axial Zone of the Pyrenees is due to the scarcity of post-Variscan markers. Syn-kinematic mica in some ductile shear zones has been tentatively dated using ${ }^{40} \mathrm{Ar} /{ }^{39} \mathrm{Ar}$ methods and provided ages ranging between the Eocene and the Jurassic (e.g. McCaig \& Miller, 1986; Monié et al., 1994; Wayne \& McCaig, 1998; Vissers et al., 2017). Eocene ages suggest a partial Pyrenean reactivation of some shear zones, as for instance in the Néouvielle massif (Wayne \& McCaig, 1998). Nevertheless, ${ }^{40} \mathrm{Ar} /{ }^{39} \mathrm{Ar}$ ages on mica cannot be readily used as proxies for the absolute age of faults or shear zones. The closure temperature of the Ar/Ar system in mica is around $300{ }^{\circ} \mathrm{C}$ (Harrison et al., 
1985), but the Jurassic to Cretaceous ages in Pyrenean shear zones suggest a partial to total

191 rejuvenation of argon isotopic systems during the widespread hydrothermal events $(250<T<$

$192550^{\circ} \mathrm{C}$ ) that occurred between Permian and Cretaceous times (Boulvais et al., 2007; Poujol et

193 al., 2010; Fallourd et al., 2014; Boutin et al., 2016, Boutin, 2016). The difficulties linked to

194 interpreting ${ }^{40} \mathrm{Ar} /{ }^{39} \mathrm{Ar}$ ages in the Pyrenees have been emphasized by Jolivet et al. (2007), Maurel

195 et al. (2008) and Metcalf et al. (2009), who recognized the effects of the Mesozoic hydrothermal

196 events in the syn-kinematic micas of the Variscan Maladeta and Néouvielle plutons, and in the

197 Canigou massif.

Methodology

\section{Measurement and sampling}

This study is based on 330 sites distributed along N-S cross-sections, following the main

201 valleys of the mountains belt (Fig. 2). In order to reconstruct the large-scale geometry of folds, planar and linear strain fabrics and kinematic criteria affecting metasedimentary rocks were systematically measured, as well as the relationship of planar fabric with original bedding. All these measurements are synthesized in Figs. 3 and 4.

Nineteen samples were collected along the Pallaresa cross-section. They were selected in the whole metasedimentary sequence from Cambrian to Devonian (Fig. 2, red dots). At least two samples were collected in each structural domain of the cross-section. Dark-coloured samples rich

208 in organic matter were favoured for Raman Spectroscopy of Carbonaceous Materials (RSCM). Polished thin sections were prepared normal to the schistosity and parallel to the lineation

210 (XZ planes) for petrographic and microstructural observation. 
213 maximum temperature (up to $650{ }^{\circ} \mathrm{C}$ ) recorded by the metasediments during metamorphism 214 (Beyssac et al., 2002; Lahfid et al., 2010). Delchini et al. (2016) confirmed the applicability of RSCM for studying domains with polyphased metamorphic histories, such as the Pyrenees. Raman analyses were performed at the BRGM, Orléans, using a Ranishaw inVia Reflex system with argon-ion laser source excitation of $514.5 \mathrm{~nm}$. The laser beam is focussed on the sample through 218 a Leica DM2500 microscope specially adapted for the system using a x100 lens, with power of around $0.5 \mathrm{~mW}$ at the surface of the thin section. Before each measurement session, the spectrometer was calibrated using the $520.5 \mathrm{~cm}^{-1}$ line of a silicon standard. The signal obtained after elimination of Rayleigh diffusion using Edge filters was dispersed using 1800 lines.mm ${ }^{-1}$ grating before being analyzed by a deep depletion CCD detector (1024 x 256 pixels). About 1520 Raman spectra of particles were recorded to check data consistency. Raman parameters, peak temperatures obtained by RSCM and Raman spectra are provided in the Data Repository.

\section{Structures and kinematics}

In the study area we observed two types of schistosity. The first generation is penetrative, observed in all Variscan rocks, and called hereafter S1. The second generation is only locally observed and corresponds to a crenulation cleavage. To the south of the Axial Zone, the Cambrian series belonging to the Orri anticline are unconformably overlapped by undeformed Permian and

231 Triassic red beds that crosscut the S1 cleavage (Fig. 5a). These observations attest, in accordance with previous studies (e.g. Zandvliet, 1960; Mey, 1968; Lucas, 1985; Zwart, 1986; Bichot, 1986;

233 Carreras \& Debat, 1996) that the regional penetrative cleavage S1 is Variscan in age. By contrast, 234 a discrete crenulation cleavage is observed in Permian and Triassic pelitic levels suggesting that 
235 the second schistosity in the basement units could be Alpine in age (Izquierdo-Llavall et al., 2013).

236 It is hereafter named Sa.

As a first approximation, the Central Pyrenees area is defined by two large and open antiforms forming the Pallaresa and Orri anticlines and the southward verging and pinched Llavorsi syncline (Fig. 3a). The flat attitude of bedding in anticline cores is perturbed by multiscale open to isoclinal folds (Fig. 4) associated with pervasive axial-plane cleavage (i.e. S1; Fig. 5b \& b'). S1 shows a homogeneous N95-110E direction (Fig. 3b) with trajectories roughly parallel to the Lladorre-Mérens, Estarón and Llavorsi mylonitic shear zones (Fig. 3a). In the northern half of the Axial Zone, S1 is vertical and dips around $50-60^{\circ} \mathrm{N}$ in the southern part, excepted $5 \mathrm{~km}$ to the north to the Nogueres Unit, where it is subhorizontal or displays shallow dips to the north (Figs 3a \& 4). S1 bears steeply-plunging stretching lineations with a homogeneous N150-160 orientation (Figs 3a \& 3c).

Structural studies have highlighted three domains of deformation limited by the Lladorre-Mérens and Llavorsi mylonitic shear zones. The northern domain is characterized by a vertical cleavage S1 and an apparent heterogeneous deformation, with highly transposed

251 Devonian to Cambrian limestone and schist and gently folded thick Cambrian microconglomerate and sandstone. This domain is affected by an apparent coaxial deformation attested by the coexistence of "north-side up" and "south-side up" shear criteria on subvertical

254 shear planes. This domain is limited to the south by the 200-m-thick mylonitic shear zone of 255 Lladorre, localized in interbedded sandstones and marbles showing non-coaxial "north-side up" 256 kinematics (Figs 3a, 4 \& 5c). The central domain is mostly characterized by the complete transposition of original bedding and associated non-coaxial "top-to-the-south" shear bands (Fig. 
laminated Silurian black shales. The southern domain, which corresponds to the Orri anticline,

261 is poorly deformed, marked by discrete $\mathrm{S} 1$ cleavage oblique to the original bedding. Few discrete

262 C' shears with non-coaxial "top-to-the-south" kinematics were observed, as previously described 263 by Mey (1968).

The S1 trajectories are locally disturbed in the contact aureole of plutons where asymmetric schistosity triple points can be defined (Fig. 3a). Stretching lineations are subhorizontal in these domains, with $\mathrm{C}^{\prime}$ shear bands showing dextral senses of movement (Fig. 6a). Shear bands strike between $\mathrm{N} 100-\mathrm{N} 130^{\circ} \mathrm{E}$ and concentrate in narrow mylonitic corridors such as the western part of the Estarón thrust, between the Maladeta and Marimanha plutons (Fig. 3a), or around the Bassiès pluton (Fig. 4).

Over the entire area, the Paleozoic basement is locally affected by late Alpine deformation, mainly localized within 1- to 100-m-thick corridors (Fig. 4). In such corridors, new 0.1- to 1-mscale folds $(\mathrm{Fa})$, with $\mathrm{N} 80^{\circ}$ - to $\mathrm{N} 140^{\circ}$-striking fold axes, affect previously schistose rocks forming kink-bands and chevron folds (Figs. $3 b \& 3 c$ and $6 b \& 6 c$ ). Crenulation cleavage Sa is common in such corridors. This crenulation cleavage, axial plane of late folds, is sub-vertical in the northern third part of the Axial Zone, striking at a low angle to the regional schistosity S1. In the central part of the Axial Zone, Sa dips steeply to the south (Fig. 6b) and can be easily distinguished from S1, which dips northward (Fig. 4, between Lladorre and Llavorsi). In the southern domain, which corresponds to the Orri anticline, the late crenulation cleavage dips at low angles to the north but seems to be less conspicuous than elsewhere (Fig. 4). Away from these corridors, only a subhorizontal east-west discrete crenulation lineation affects the regional structures. Evidence of 281 brittle deformation is otherwise scarce in the Pallaresa cross-section. Some fault zones have been 282 observed in the Silurian black shales of the pinched Llavorsi syncline. These faults are associated with reverse drags that affect the regional penetrative structures over distances of $\sim 20 \mathrm{~m}$. 
The Raman spectroscopy results are synthesized in Fig. 7. Palaeotemperatures range between $350{ }^{\circ} \mathrm{C}$ and $550{ }^{\circ} \mathrm{C}$ with a temperature around $350{ }^{\circ} \mathrm{C}$ in the Couflens syncline, the Llavorsi syncline and the Orri anticline and an increase up to $550{ }^{\circ} \mathrm{C}$ in the Pallaresa anticline. Two significant steps of around $50{ }^{\circ} \mathrm{C}$ and $100{ }^{\circ} \mathrm{C}$ were observed in the vicinity of the Estarón thrust and the Lladorre shear zone, respectively (Fig. 7a). Isotherms were deduced from the Raman temperature (Fig. 7a). Small steps of maximum $30{ }^{\circ} \mathrm{C}$ were evidenced in the Couflens syncline, 292 but these variations cannot be considered as significant in regard of the analytical error on the measurements.

\section{Metamorphic parageneses and microstructures}

The optical analysis of the thin sections allowed us to determine the metamorphic parageneses and microstructures and to gain insights into the thermal conditions of deformation in addition to RSCM results. The Devonian sequence in the north (16BL44, 16BL47, 16BL51, 16BL55, 16BL59), close to the NPF, corresponds to limestone with pelitic intercalations. Silurian deposits that belong to the Couflens syncline are dark schists rich in carbonaceous materials 300 (16BL60, 16BL52, 16BL53), with few small chlorite crystals. The northermost Cambrian samples consist of an alternation of thin pelitic and carbonate levels (16BL56) and quartzo-pelitic schist (TP442). The following two samples of the Pallaresa anticline (15BL104, 15BL106) correspond to quartz-rich schist with Ms-Bt-Pl-Qtz (see Kretz, 1983 for the mineral abbreviations). Biotite

304 porphyroblasts have grown parallel to S1. Quartz-rich levels show well-developed dynamic 305 recristallization controlled by grain boundary migrations, attested by a pinning effect on the migrating boundaries (Fig. 8a, Song and Ree, 2007). These types of microstructure and the observation of secondary biotites in schistosity planes suggest a temperature close to $500{ }^{\circ} \mathrm{C}$ during 
apparition of biotite and the absence of andalusite, cordierite and staurolite, which appear above a

310 temperature of $550-600{ }^{\circ} \mathrm{C}$ in the pseudosections obtained for similar protoliths from the western

311 Aston dome termination (Mezger \& Régnier, 2016) and the Albères massif (Vilà et al., 2007).

312 Within the Lladorre shear zone (samples 15BL110 \& 15BL112), well-preserved quartz veins in

313 mylonitic marble show dynamic recrystallization of quartz with an association of sub-grain

314 rotation and grain boundary migration. The transition between these two mechanisms suggests a

315 temperature of deformation at about $500-550{ }^{\circ} \mathrm{C}$ (Stipp et al., 2002). A sheared conglomerate that

316 belongs to the upper Ordovician of the southern overturned limb of the Pallaresa antiform and

317 located within the Estarón shear zone (sample 15BL118, Fig. 5d) is composed of Ms-Pl-Qtz \pm Chl

318 matrix and clasts of quartz. Here, S1 and shear bands are underlined by muscovite (Fig. 8b). Quartz

319 grains show evidence of recrystallization by bulging and sub-grain rotation (Fig 8c \& d).

320 Conglomerates show a core and mantle microstructure with grain-size of quartz blasts of about 20

321 to $50 \mu \mathrm{m}$, suggesting a recrystallization temperature of about $400{ }^{\circ} \mathrm{C}$ (Stipp et al., 2002). Finally,

322 the two southernmost samples (15BL125, 15BL127) are Cambrian schists from the Orri anticline,

323 with muscovite and chlorite growing parallel to S1 (Fig. 8e).

324 The evolution from biotite-bearing schist in the Pallaresa anticline to chlorite-bearing schist

325 in Orri anticline, in addition to the quartz recrystallization dynamics, indicate a decrease in

326 palaeotemperature towards the south, which is in good agreement with RSCM results. All along

327 the cross-section, the second cleavage Sa is characterized by microfolds, forming microlithons that

328 affect S1 (Fig. 8e). The development of Sa implies the progressive destruction of previous fabrics

329 by pressure solution, mainly removing quartz grains while phyllosilicates show internal

330 deformation like folding and rotation. In agreement with previous work (Zwart, 1986; Bons, 1988;

331 Soler et al., 1998; Clariana et al., 2008, among others), our observations confirm that Alpine

332 structures in Central Pyrenees were produced under low temperatures, which never reached those

333 obtained during the Variscan orogeny 
Given that greenschist and amphibolite facies metamorphic minerals grew within shear planes and underline the main schistosity plane S1, our petrological study highlights that HT-LP metamorphism was synchronous with pervasive deformation. We determined the geometry of the palaeo-isotherms based on the following constraints. The isotherms match the temperatures retrieved from Raman spectroscopy (Fig. 7a). They also account for the absence of abrupt 340 petrological transitions across the section, with regular transitions from greenschist to amphibolite 341 facies assemblage. The isotherms are drawn parallel to each other. They match the geothermal 342 gradient previously estimated in the envelope of the Aston, Albères, Bossost and Canigou gneiss 343 domes (40 to $70{ }^{\circ} \mathrm{C} / \mathrm{km}$ ) (Mezger, 2005; Triboulet et al., 2005; Vilà et al., 2007; Mezger \& 344 Régnier, 2016). We end up with a picture of relatively flat isotherms that define a 345 palaeogeothermal gradient of $45^{\circ} \mathrm{C} / \mathrm{km}$ (Fig. 7b).

On the cross-section in Fig. $7 \mathrm{~b}$, isotherms are secant on large-scale folds, such as the 347 Llavorsi syncline. This first-order observation allows us to interpret the metamorphism as 348 subsequent to the initiation of regional-scale folding. Besides, isotherms are vertically shifted by 349 the Lladore and Estarón amphibolite to greenschist facies reverse shear zones, suggesting that 350 shear zone activity ends after peak metamorphism. Our results show (i) that shear zones and 351 regional cleavage form a single and continuous fabric that simply illustrates the strain gradient in 352 the crust; (ii) that mylonites within the shear zones and rocks affected by the regional cleavage 353 exhibit the same amphibolite to greenschist metamorphic parageneses; and (iii) that the regional 354 fabrics and shear zone share the same structural character, with down-dip stretching lineations and 355 dip-slip/reverse sense of shear. Based on this evidence, we consider these shear zones as Variscan 356 in age. They formed during the same tectonic episode as the other regional structures. Because the 357 Lladorre and Estarón amphibolite to greenschist facies reverse shear zones shift the isotherms (Fig. 7b), we propose that their final activity occurred after peak metamorphism and represents the final 
expression of the main Variscan deformation recorded in Pyrenees (see discussion below). This

360 interpretation as such does not refute the notion of a possible reactivation of the shear zones during 361 the Pyrenean orogeny, which was previously proposed by Mc Caig (1986) on the basis of Ar/Ar 362 dating.

\section{Variscan tectono-metamorphic evolution of the Central Pyrenees}

Based on new structural and petrological observations, we propose hereafter a scenario for the Variscan tectono-metamorphic evolution of the Central Axial Zone of the Pyrenees.

During the first stage of Variscan evolution, the upper crust was affected by regional-scale folding, producing kilometre-scale open to tight southward verging folds with an east-west axial plane (Fig. 9a). We consider them as the first expression of Variscan transpression in the Axial Zone. At this time, the mid to lower crust (Infrastructure) was probably affected by upward-propagating HT-LP metamorphism (Fig. 9a). Note that faults recognized along the Pallaresa cross-section, with a subtractive character and apparent "north side down" movement (Port de Salau and

372 Llavorsi faults), are folded and must have formed prior to this stage. Because of penetrative 373 deformation that occurred during the next stage and of the difficulty to evaluate the amount of 374 thickening, the thickness of each sedimentary unit in our reconstruction (Fig. 9a) remains 375 speculative. Moreover, we consider the existence of a large syn-orogenic Carboniferous basin, 376 similar to the Arreau bassin located a few kilometres to the west of the Palaressa cross-section 377 (Delvolvé, 1987).

378 During the second stage of Variscan evolution, the upper crust was affected by intense 379 horizontal shortening and vertical stretching producing multi-scale isoclinal folding and the 380 formation of pervasive cleavage (Fig. 9b). In the central and northern part of the Axial Zone, the 381 upper crust was affected by apparently coaxial shearing, while the southern part was the focus of 382 non-coaxial "top-to-the-south" reverse kinematics, illustrating strain partitioning within the upper 
crust. Non-coaxial shearing is responsible for the amplification of the overturned Pallaresa anticline (Fig. 9b). This event occurred at peak metamorphism, leading to the crystallization of biotite, muscovite and chlorite in cleavage planes.

During a third stage, strain localization occured with formation of 100-m-thick shear zones under amphibolite-greenschist conditions (Fig. 9c). The Lladorre and Estarón reverse shear zones were responsible for vertical offsets of the isotherms by $\sim 2 \mathrm{~km}$ and $1 \mathrm{~km}$, respectively. Similar displacement can be deduced from the offset of the sedimentary pile for the Lladorre shear zone (Fig. 4). At this stage, the dome shape of the Infrastructure was amplified by the displacement along shear zones (Fig. 9c). This interpretation is in agreement with structural observations made in the rest of the Axial Zone, where it has been shown that domes were lately amplified and affected by steep transpressional shear zones, showing retrogressive parageneses (Denèle, 2007; Vilà et al., 2007; Denèle et al., 2008, 2009).

\section{Evolution of the Central Pyrenees during Cretaceous rifting and Pyrenean collision}

\section{Cretaceous rifting}

The Cretaceous rifting event has strongly reworked the North Pyrenean Zone, which belongs to the European plate. Markers of this event correspond to: (i) late Aptian to early Cenomanian rift basins filled by flysch-type sediments (Debroas, 1987, 1990; Bodego et al., 2015; Chelalou et al., 2016); (ii) regional HT-LP metamorphism with temperatures locally reaching 600 ${ }^{\circ} \mathrm{C}$ (Vielzeuf \& Kornprobst, 1984; Dauteuil \& Ricou, 1989; Golberg \& Leyreloup, 1990; Clerc \& Lagabrielle, 2014; Vacherat et al., 2014) and widespread metasomatism (Schärer et al., 1999; Boulvais et al., 2007; Poujol et al., 2010; Fallourd et al., 2014; Boutin et al., 2016); (iii) exhumation of sub-continental mantle bodies (Fabries et al., 1991; Clerc et al., 2012; de Saint Blanquat et al., 2016). 
407 present, the Mesozoic sediments unconformably deposited over the Variscan basement correspond 408 to post-rift Cenomano-Turonian flysch (Ternet et al., 1980, 2003; Clin et al., 1986; Mirouse et al., 409 1993; Majeste-Menjoulas et al., 1999). In the Central Pyrenees, our structural and petrological study coupled with RSCM shows that (i) all vertical offsets display reverse motion, and (ii) the 411 only thermal event recorded in the area is related to Variscan HT-LP metamorphism, with no sign 412 of any later thermal overprint. These first-order observations suggest that the Axial Zone was 413 relatively preserved during Cretaceous rifting. Evidence of Cretaceous rifting concern only the 414 borders of the Axial Zone and remains scarce. Indeed, in the study area, Triassic ophites are 415 described as intrusive into Paleozoic and Triassic sedimentary rocks in a fault zone near Couflens 416 (Fig. 2; Ternet et al., 1997). Proximity between this fault zone and evidence of metasomatism with 417 talc formation (Ternet et al., 1997) of Cretaceous age (Boutin et al., 2016) suggests fault 418 (re)activation during the rifting event (Fig. 9d). In the western part of the Axial Zone, normal 419 faulting is indicated by the remains of syn-rift deposits (Casteras et al., 1971; Ternet et al., 1980, 420 2003), which can be observed against the North-Pyrenean Fault. Along the North Pyrenean Fault 421 east of the study area, evidence of major Cretaceous metasomatism has been discovered, with 422 albitized rocks and talc occurrences (Fallourd et al., 2014). On the southern border of the Axial 423 Zone, the formation of the Organyà Basin, which is described as a piggy-back basin with syn-rift 424 Aptian to Albian deposits, is supposed to be related to a normal movement along the future Orri 425 thrust (Fig. 9d, García Senz, 2002; Martinez-Peña \& Casas-Sainz, 2003; Mencos et al., 2015).

\section{Late Cretaceous to Cenozoic convergence}

In the southern part of the Axial Zone, alpine movement along the Orri thrust is undeniable,

428 highlighted by the Rialp window (Fig. 2 \& 3), probably responsible for tilting of Variscan 429 structures in the Orri anticline (Bons, 1988; Carreras \& Debat, 1996). At depth, the Rialp thrust is 
430 inferred from the ECORS seismic profile but has no geological incidence at the surface. Along the

431 North Pyrenean Fault, Alpine deformation is marked by refolded Variscan structures and folds in

432 Permo-Triassic sediments (Déramond, 1970; Ternet et al., 1997), as well as the reactivation of

433 inherited vertical faults marked by the uplift of the northern blocks over several hundred metres to

434 a few kilometres (Fig. 9d \& e). Across the rest of the Axial Zone, there is no significant Alpine

435 deformation, except in narrow corridors highlighted in Fig. 4 where crenulation cleavage was

436 produced (Fig. $6 b$ \& 6c). So, except along the North Pyrenean Fault and few kilometres above the

437 Orri thrust, no significant Alpine fault or penetrative deformation are observed, leading to the

438 conclusion that Variscan structures appear continuous and mainly undisturbed in the central Axial

439 Zone (Fig. 4).

\section{Discussion}

The constrasted response to Early Cretaceous rifting of the European and Iberian margins,

442 which are represented respectively by the North-Pyrenean Zone and the Axial Zone, suggests an

443 asymmetric rift system (Fig. 10a). The European margin of this rift shows a large distal domain,

444 which comprises the inverted syn-rift basins of Camarade, Saint-Girons and Aulus (e.g.

445 Mouthereau et al., 2014). The quantity of extension increased southward in this distal domain and

446 has led to the exhumation close to the surface of mantle rocks in the Aulus Basin (Fig. 10a). These

447 observations show that this rift system was mature and led to the breakup of the continental crust.

448 By contrast, the Iberian margin shows a large proximal domain with the relatively preserved Axial

449 Zone block and a restricted distal domain, localized near the North-Pyrenean fault zone.

450 Asymmetrical conjugate margins have been evidenced in numerous purely extensional palaeo-rift

451 systems (Chian et al., 1995; Ranero \& Pérez-Gussinyé, 2010; Blaich et al., 2011; Espurt et al.,

452 2012; Peron-Pinvidic et al., 2013; Sutra et al., 2013). However, a sinistral displacement has been

453 deduced from motion of the Iberian plate in Cretaceous times (Le Pichon et al., 1970; Choukroune 
et al., 1973; Choukroune \& Mattauer, 1978; Olivet, 1996), suggesting that the Pyrenean rift system occurred under a transtensional stress regime. Furthermore, most of the syn-rift basins in the

North-Pyrenean Zone of the Central Pyrenees correspond to narrow pull-apart basins (Debroas, 1987). In transtensional settings, strain can be partitioned into purely extensional domains and narrow strike-slip or transform faults (Allen et al., 1998; Wu et al., 2009), which could explain the degree of asymmetry of the Pyrenean rift system. Here we advocate that the North-Pyrenean Fault represents a transform fault that has accommodated the abrupt variation of extensional patterns between the Iberian and European plates during Cretaceous rifting (Fig. 10a). Further west, in the Basque massifs, the conjugate margins appear to be more symmetrical (Roca et al., 2011; Masini et al., 2014; Tugend et al., 2014) and the the North-Pyrenean Fault has never been identified. This feature highlights the segmentation of the Pyrenean rift system along the strike of the mountain belt.

Concerning the inversion of the rift system, classical models of the Pyrenean orogenic wedge have involved various basement thrust units in the Axial Zone and imply large-scale block rotations and internal deformation of these units (e.g. Beaumont et al., 2000). These basement units have been clearly identified in the western part of the Axial Zone, such as the Lakhora and 470 Gavarnie units (Teixell, 1996), in its southernmost part with the Orri and Rialp units in the Central 471 Pyrenees (e.g. Muñoz, 1992), and in the western Pyrenees with the Bielsa/Millares units (Teixell, 472 1996; Jolivet et al., 2007). Based on the interpretation of the ECORS seismic profile, Muñoz 473 (1992) had proposed that the Nogueres sheet was rooted in the Axial Zone in the Central Pyrenees, 474 and was an eastward prolongation of the Gavarnie thrust. In this currently accepted model, the 475 Nogueres sheet would have been displaced to the south over a distance of 15-20 km (Berastegui 476 et al., 1993; Beaumont et al., 2000). However, our results in the Axial Zone do not support such a 477 model. We show instead that the main localized structures of the Central Pyrenees are ductile 478 amphibolite to greenschist facies Variscan shear zones with only limited evidence of late 
reactivation, and are associated with a motions that do not exceed 1-2 km (Figs. 4 \& 7). Even if

480 the reactivation of these Variscan shear zones was responsible for these kilometre-scale offsets, the evidence does not support the existence of a basement nappe rooted in the central part of the Axial Zone. Furthermore, despite intense deformation of the Superstructure during the Variscan orogeny, where upright isoclinal folds are common, the envelope of the stratigraphic markers remained roughly horizontal, as was that of the Infrastructure's roof and its metamorphic isograds (Figs. 4 \& 7). Furthermore, thermochronogical data in Central Pyrenees show that the Nogueres unit and the Orri unit (Vergés et al., 1995, Teixell et al., 1998) have shared similar exhumation histories since late-Eocene times (Fig. 10c) (Fitzgerald et al., 1999; Sinclair et al., 2005). Fault in the north and the Orri thrust in the south (Fig. 10b, Laumonier, 2015). In this scheme, the "têtes plongeantes" or "Plunging noses" (Séguret, 1972; Choukroune and Séguret, 1973) defined to the south of the Axial Zone should be reinterpreted as cover nappes originating in the Axial Zone or in the North Pyrenean Zone, and transported to its southern border by successive thrusting and décollements at the base of the Mesozoic cover and downward in the Silurian black shales. Given that the Nogueres allochtonous unit corresponds to the uppermost Paleozoic series and are devoid of syn-rift sequences as well as HT-MP metamorphic rocks that characterized the North 496 Pyrenean massifs, we interpret this unit as belonging to the top of the Axial Zone. These cover nappes, which share the same exhumation histories as the Maladeta and Marimanha massifs (Fig.

498 10c), were disconnected from the Axial Zone by the exhumation of the Orri units in Oligocene 499 times. If the amount of convergence of the Iberian plate, around $150 \mathrm{~km}$ since $83 \mathrm{Ma}$ (Olivet, 1996; 500 Sibuet et al., 2004; Vissers \& Meijer, 2012) is correct, the estimates and the spatial distribution of 501 shortening in the Pyrenean belt, especially within the Axial Zone, should be re-examined. Indeed, 502 the total amount of convergence has been explained by a combination of subduction and crustal thickening (Beaumont et al., 2000). This later included 15-20 km of displacement of the Nogueres 
nappe when considered as rooted in the Axial Zone. Furthermore, $10-15 \mathrm{~km}$ of shortening by pervasive internal deformation has been inferred in order to match the total convergence (Roure et al., 1989; Muñoz, 1992; Mouthereau et al., 2014). Given our interpretation of structures in the Central Pyrenees, these ca. $30 \mathrm{~km}$ of horizontal shortening by crustal thickening in the basement must be found elsewhere, for example in a greater amount of subduction of the Iberian plate.

The relative stability of the Axial Zone block since Paleozoic times highlighted the critical role of crustal-scale inherited structures from the Cretaceous rifting event on the geometry of the Cenozoic orogenic wedge. Convergence was first accommodated between 85 and 70 Ma within the thinned European margin, leading to the inversion of syn-rift basins and the accretion of microcontinental blocks that form the North Pyrenean massifs (Mouthereau et al., 2014; Ford et al., 2016; Vacherat et al., 2016) (Fig. 10b). Deformation then propagated southward during Eocene times into the moderately thinned Iberian crust, but remained focused around the main normal faults inherited from the Cretaceous. The reactivation of these normal faults as crustal-scale thrusts seems to have been sufficient to initiate the subduction of a part of the Iberian plate under the accreted European plate and the Axial Zone block, defining a pop-up structure (Fig. 10b; Brun, 2002). Given that the main shear zones of the Axial Zone remained preserved after Alpine collision, the role of inherited structures from the pre-rift events appears to be negligible in this scenario. The importance of the North-Pyrenean Fault, however, which formed a boundary between two continental margins with contrasting behaviours during rifting, and later between two contrasting pro- and retro-wedge domains during collision, is nonetheless also confirmed by our study. Most previous reconstructions had likewise considered that this fault was inherited from the Variscan orogenic cycle (Arthaud \& Matte 1975; Burg, 1994; Carreras \& Capella, 1994; Matte, 2001, Stampfli et al., 2013).

\section{Conclusion}



relationship with regional metamorphism in the Central Pyrenees. The present-day structure of the

530 Central Pyrenees results from a multi-stage Variscan-Cretaceous-Alpine history. The central part of the Axial Zone represents an upper crustal sequence deformed under a transpressional regime in Variscan times, and is characterized by (i) regional to small-scale folds, (ii) steep penetrative axial-plane cleavage, and (iii) greenschist to amphibolite facies metamorphism associated to a HT-

534 LP gradient. The flat pattern of Paleozoic stratigraphic and Variscan metamorphic markers all 535 along the north-south cross-section of the Central Pyrenees, along with the absence of Cretaceous 536 and Pyrenean crustal-scale faults in the core of the Axial Zone, highlight that this domain has been 537 preserved from both rift- and collision-related overprints. Thus, in Cretaceous times, the Axial 538 Zone formed a single continental bloc separated by the North Pyrenean Fault from the hyper539 extended domain that formed the northern margin. Finally, the "Têtes plongeantes" units located 540 south of the Axial Zone are re-interpreted here as cover nappes, detached from the central-southern 541 upper part of the Axial Zone by faulting between the basement and the Mesozoic cover during the

542 Cenozoic. In our model, the Axial Zone would thus correspond to a pop-up structure overthrusting 543 its southern foreland. It contradicts the widely accepted view of an antiformal nappe stack in the 544 core of the Axial Zone, previously elaborated by Muñoz (1992). Alpine shortening was restricted 545 to the northern and southern borders of the Axial Zone, and focused around structures inherited 546 from Cretaceous rifting.

\section{Acknowledgements}

This work was supported by the BRGM through the Référentiel Géologique de la France

549 program (RGF). We thank D. Chardon, L. Jolivet, F. Mouthereau, J.-P. Brun, M. Ford, T. 550 Poitrenaud and R. Augier for their fruitful discussion, as well as A. McCaig, B. Laumonier and 
551 the subject editor Y. Gunnell for their constructive reviews. The structural data acquired for the 552 study will be available on the RGF website (rgf.brgm.fr).

553

554

\section{References}

555

556

Allen, M.B., Macdonald, D.I.M., Xun, Z., Vincent, S.J. \& Brouet-Menzies, C. 1998. 557 Transtensional deformation in the evolution of the Bohai Basin, northern China. Geological Society, London, Special Publication, 135, 215-229, doi:

Antolín-Tomás, B., Román-Berdiel, T., Casas-Sainz, A., Gil-Peña, I., Oliva, B. \& Soto, 561 10.1144/GSL.SP.1998.135.01.14.

564 R. 2009. Structural and magnetic fabric study of the Marimanha granite (Axial Zone of the Pyrenees). International Journal of Earth Sciences, 98, 427-441, doi: 10.1007/s00531007-0248-1.

Arthaud, F. \& MAtTe, P. 1975. Les decrochements tardi-hercyniens du sud-ouest de l'europe. Geometrie et essai de reconstitution des conditions de la deformation. Tectonophysics, $\mathbf{2 5}$, 139-171, doi: 10.1016/0040-1951(75)90014-1.

Beaumont, C., Muñoz, J.A., Hamilton, J. \& Fullsack, P. 2000. Factors controlling the Alpine evolution of the central Pyrenees inferred from a comparison of observations and geodynamical models. Journal of Geophysical Research: Solid Earth, 105, 8121-8145, doi: 10.1029/1999JB900390.

Bellahsen, N., Mouthereau, F., Boutoux, A., Bellanger, M., Lacombe, O., Jolivet, L. \& Rolland, Y. 2014. Collision kinematics in the western external Alps. Tectonics, 33, 2013TC003453, doi: 10.1002/2013TC003453. 
Berastegui, X., Losantos, M., MuÑoz, J.A. \& Puigdefabregas, C. 1993. Tall geològic del Pirineu central, 1:200,000. Publ. Geol. Catalunya, 62 pp.

BEssièRE, G. 1987. Modèle d'évolution polyorogénique d'un massif hercynien: le Massif de Mouthoumet (Pyrénées Audoises). PhD thesis, Univ. Toulouse, France.

Beyssac, O., Goffé, B., Chopin, C. \& RouZAud, J.N. 2002. Raman spectra of carbonaceous material in metasediments: a new geothermometer. Journal of Metamorphic Geology, 20, 859-871, doi: 10.1046/j.1525-1314.2002.00408.x.

Віснот, F. 1986. La tectonique distensive carbonifère dans les Pyrénées. Corrélations estcanadiennes et ouest-européennes. PhD thesis, Univ. Bordeaux, France.

BlAich, O.A., FALEIDE, J.I. \& TsiKALAS, F. 2011. Crustal breakup and continent-ocean transition at South Atlantic conjugate margins. Journal of Geophysical Research: Solid Earth, 116, B01402, doi: 10.1029/2010JB007686.

Bodego, A., Iriarte, E., Agirrezabala, L.M., García-MondéJar, J. \& LóPeZ-Horgue, M.A. 2015. Synextensional mid-Cretaceous stratigraphic architecture of the eastern BasqueCantabrian basin margin (western Pyrenees). Cretaceous Research, 55, 229-261, doi: 10.1016/j.cretres.2015.01.006.

BoDIN, J. \& LEDRU, P. 1986. Nappes hercyniennes précoces à matériel dévonien hétéropique dans les Pyrénées ariégeoises. Comptes Rendus de l'Académie des Sciences, Paris, 302, II, 969974.

BonS, A.J. 1988. Intracrystalline deformation and slaty cleavage development in very low-grade slates from the Central Pyrenees. Geologica Ultraiectina, 56. 
595

596

597

598

599

600

601

602

603

604

605

606

607

608

609

610

611

612

613

614

615

BoucheZ, J.L. \& GLEIZES, G. 1995. Two-stage deformation of the Mont-Louis-Andorra granite pluton (Variscan Pyrenees) inferred from magnetic susceptibility anisotropy. Journal of the Geological Society, 152, 669-679, doi: 10.1144/gsjgs.152.4.0669.

Boulvais, P., Ruffet, G., Cornichet, J. \& Mermet, M. 2007. Cretaceous albitization and dequartzification of Hercynian peraluminous granite in the Salvezines Massif (French Pyrénées). Lithos, 93, 89-106, doi: 10.1016/j.lithos.2006.05.001.

Boutin, A. 2016. Étude des conditions de formation du gisement de talc-chlorite de Trimouns (Ariège, France). $\mathrm{PhD}$ thesis, Univ. Toulouse, France.

Boutin, A., Blanquat, M. De S., Poujol, M., Boulvais, P., Parseval, P. De, Rouleau, C. \& Robert, J.-F. 2016. Succession of Permian and Mesozoic metasomatic events in the eastern Pyrenees with emphasis on the Trimouns talc-chlorite deposit. International Journal of Earth Sciences, 105, 747-770, doi: 10.1007/s00531-015-1223-x.

BRUN, J.-P. 2002. Deformation of the continental lithosphere: Insights from brittle-ductile models. Geological Society, London, Special Publication, 200, 355-370, doi: 10.1144/GSL.SP.2001.200.01.20.

BuRG, J.-P., VAN DEN DRIESSCHE, J., BRUN, J.-P., 1994. Syn- to post-thickening extension in the Variscan Belt of Western Europe: Mode and structural consequences. Géologie de la France, 3, 33-51.

CAPElla, I. \& Bou, O. 1997. La estructura del domo de la Rabassa y del sector oriental del sinclinal de Llavorsí (Pirineo Central). Estudios Geológicos, 53, 121-133, doi: 10.3989/egeol.97533-4237. 
616 CAPElla, I. \& CARRERAS, J. 1996. La zonación estructural del hercínico del Pirineo Central en el 617 anticlinorio de la Pallaresa. Estudios Geológicos, 52, 51-61, doi: 10.3989/egeol.965216182253.

619 CARreras, J. \& CAPELla, I. 1994. Structures and Tectonics at Different Lithospheric Levels 620 Tectonic levels in the Palaeozoic basement of the Pyrenees: a review and a new interpretation. Journal of Structural Geology, 16, 1509-1524, doi: 10.1016/01918141(94)90029-9.

CARreras, J. \& Debat, P. (eds) 1996. Tectonique Hercynienne. In: Synthèse Géologique et 624 Géophysique des Pyrénées. BRGM-ITGE, 501-584.

Casas, J.M., Domingo, F., Poblet, J. \& Soler, A. 1989. On the role of the Hercynian and Alpine 626 thrusts in the Upper Palaeozoic rocks of the Central and Eastern Pyrenees. Geodinamica Acta, 3, 135-147, doi: 10.1080/09853111.1989.11105181.

CASAs, J.M., FernándeZ, O. \& Domingo, F. 2007. Carboniferous normal faults in the Eastern 629 Pyrenees: evidences and age constrains of syn-orogenic Variscan extension. Geodinamica

Casteras, M., Gottis, M., Clin, M., Guignard, J.D., Paris, J.-P., Galharague, J. \& Frey, 632 M. 1971. Carte Géologique de la France (1/50 000), Feuille de Tardets Sorholus (1971), BRGM. Orléans.

Chelalou, R., NALPAS, T., ET AL. 2016. New sedimentological, structural and paleo-thermicity 635 data in the Boucheville Basin (eastern North Pyrenean Zone, France). Comptes Rendus 636 Géoscience, 348, 312-321, doi: 10.1016/j.crte.2015.11.008. 
CHIAN, D., LOUDEN, K.E. \& REID, I. 1995. Crustal structure of the Labrador Sea conjugate margin and implications for the formation of nonvolcanic continental margins. Journal of Geophysical Research: Solid Earth, 100, 24239-24253, doi: 10.1029/95JB02162.

Choukroune, P. 1976. Structure et évolution tectonique de la zone nord-pyrénéenne: analyse de la déformation dans une portion de chaîne à schistosité sub-verticale. Mémoire de la Société Géologique de France, 127, 176 p.

Choukroune, P. 1989. The Ecors Pyrenean deep seismic profile reflection data and the overall structure of an orogenic belt. Tectonics, 8, 23-39, doi: 10.1029/TC008i001p00023.

ChOukroune, P. 1992. Tectonic evolution of the Pyrenees. Annual Review of Earth and Planetary Sciences, 20, 143-158.

Choukroune, P. \& Mattauer, M. 1978. Tectonique des Plaques et Pyrénées: sur le fonctionnement de la faille transformante nord-pyrénéenne; comparaisons avec des modèles actuels. Bulletin de la Société Géologique de France, XX, 689-700.

Choukroune, P. \& SÉguret, M. 1973. Tectonics of the Pyrenees: role of compression and gravity. In: De Jong, K.A., Scholten, R. (eds). Gravity and Tectonics. Wiley, 141-156.

Choukroune, P., SÉGuret, M. \& Galdeano, A. 1973. Caractéristiques et évolution structurale des Pyrénées : un modèle de relations entre zone orogénique et mouvement des plaques. Bulletin de la Société Géologique de France, 7, 600-611.

Choukroune, P., Roure, F. \& Pinet, B. 1990. Main results of the ECORS Pyrenees profile. Tectonophysics, 173, 411-423. 
Clariana, P. 2001. Significado de los pliegues N-S en el área del río Civis. Sector oriental del flanco sur del sinclinal de Llavorsí (Zona Axial, Pirineos Centrales). Boletín geológico y minero, 112, 39-46.

Clariana, P. \& García-SANSEgundo, J. 2009. Variscan structure in the eastern part of the Pallaresa massif, Axial Zone of the Pyrenees (NW Andorra). Tectonic implications. Bulletin de la Société géologique de France, 180, 501-511, doi: 10.2113/gssgfbull.180.6.501.

CLERC, C. 2012. Evolution du domaine nord-pyrénéen au Crétacé : amincissement crustal extrême et thermicite élevée: un analogue pour les marges passives. $\mathrm{PhD}$ thesis, Univ. Paris 6, France.

Clerc, C. \& Lagabrielle, Y. 2014. Thermal control on the modes of crustal thinning leading to mantle exhumation: Insights from the Cretaceous Pyrenean hot paleomargins. Tectonics, 33, 2013TC003471, doi: 10.1002/2013TC003471.

Clerc, C., Lagabrielle, Y., Neumaier, M., Reynaud, J.-Y. \& Blanquat, M. De S. 2012. Exhumation of subcontinental mantle rocks: evidence from ultramafic-bearing clastic deposits nearby the Lherz peridotite body, French Pyrenees. Bulletin de la Société Géologique de France, 183, 443-459, doi: 10.2113/gssgfbull.183.5.443.

Clin, M., Lelong, F., ET AL. 1986. Carte Géologique de la France (1/50 000), Feuille Bagnèresde-Luchon (1084), BRGM, Orléans.

Cloke, I.R., Moss, S.J. \& CRAIG, J. 1997. The influence of basement reactivation on the extensional and inversional history of the Kutai Basin, East Kalimantan, SE Asia. Journal of the Geological Society, 154, 157-161, doi: 10.1144/gsjgs.154.1.0157. 
679 Colchen, M., Ternet, Y., Debroas, E.J., Dommanget, A., Gleizes, G., Guérangé, B. \& 680 Roux, L. 1995. Carte Géologique de la France (1/50 000), Feuille Aulus-Les-Bains 681 (1086), BRGM, Orléans.

682

683

684

685

686

687

688

689

690

691

692

693

694

695

696

697

698

699

Crochet, B., Villatte, J., ET AL. 1989. Carte Géologique de la France (1/50 000), Feuille Quillan (1077), BRGM, Orléans.

DAuTEuIL, O. \& RiCOU, L.-E. 1989. Hot-fluid circulation as an origin for the North Pyrenean Cretaceous metamorphism. Geodinamica Acta, 3, 237-249, doi: 10.1080/09853111.1989.11105190.

DE SAint Blanquat, M., BAJOlet, F., ET AL. 2016. Cretaceous mantle exhumation in the central Pyrenees: New constraints from the peridotites in eastern Ariège (North Pyrenean zone, France). Comptes Rendus Geoscience, 348, 268-278, doi: 10.1016/j.crte.2015.12.003.

DE SitTER, L.U. \& ZWART, H.J. 1962. Geological map of the Central Pyrenees. Leidse Geologische Mededelingen, 27, 191-369.

DEBROAS, E.J. 1987. Modele de bassin triangulaire a l'intersection de decrochements divergents pour le fosse albo-cenomanien de la Ballongue (zone nord-pyreneenne, France). Bulletin de la Société Géologique de France, III, 887-898, doi: 10.2113/gssgfbull.III.5.887.

DEBROAS, E.J. 1990. Le flysch noir albo-cénomanien témoin de la structuration albienne a sénonienne de la Zone nord-pyrénéenne en Bigorre (Hautes-Pyrenees, France). Bulletin de la Société Géologique de France, VI, 273-285, doi: 10.2113/gssgfbull.VI.2.273.

Delchini, S., Lahfid, A., Plunder, A. \& Michard, A. 2016. Applicability of the RSCM geothermometry approach in a complex tectono-metamorphic context: The Jebilet massif 
case study (Variscan Belt, Morocco). Lithos, 256-257, 1-12, doi: 10.1016/j.lithos.2016.04.007.

702

703

704

705

706

707

708

Delvolvé, J.-J. 1987. Un Bassin Synorogenique Varisque: Le Culm Des Pyrenees CentroOccidentales. PhD thesis, Univ. Toulouse 3, France.

DenÈle, Y. 2007. Formation Des Dômes Gneissiques Hercyniens Dans Les Pyrénées : Exemple Du Massif de l'Aston-Hospitalet. PhD thesis, Univ. Toulouse 3, France.

DenÈle, Y., Olivier, P. \& Gleizes, G. 2008. Progressive deformation of a zone of magma transfer in a transpressional regime: The Variscan Mérens shear zone (Pyrenees, France). Journal of Structural Geology, 30, 1138-1149, doi: 10.1016/j.jsg.2008.05.006.

DenÈle, Y., Olivier, P., Gleizes, G. \& Barbey, P. 2009. Decoupling between the middle and upper crust during transpression-related lateral flow: Variscan evolution of the Aston gneiss dome (Pyrenees, France). Tectonophysics, 477, 244-261, doi: 10.1016/j.tecto.2009.04.033.

Denèle, Y., Laumonier, B., Paquette, J.-L., Olivier, P., Gleizes, G. \& Barbey, P. 2014. Timing of granite emplacement, crustal flow and gneiss dome formation in the Variscan segment of the Pyrenees. Geological Society, London, Special Publications, 405, 265-287, doi: 10.1144/SP405.5.

DÉRAMOND, J. 1970. Tectoniques superposées dans le Paléozoïque du Haut-Salat (Pyrénées Ariégeoises). PhD thesis ("Thèse de 3e cycle"), Univ. Toulouse, France.

DÉRAMOnd, J. 1979. Déformation et Déplacement Des Nappes: Exemple de La Nappe de Gavarnie (Pyrénées Centrales). PhD thesis ("Thèse d'état"), Univ. Toulouse, France. 
Dubois, P. \& SEguin, J.C. 1978. Les flyschs Crétacé et Eocène de la zone commingeoise et leur environnement. Bulletin de la Société Géologique de France, S7-XX, 657-671, doi: 10.2113/gssgfbull.S7-XX.5.657.

Espurt, N., Callot, J.-P., Roure, F., Totterdell, J.M., Struckmeyer, H.I.M. \& Vially, R. 2012. Transition from symmetry to asymmetry during continental rifting: an example from the Bight Basin-Terre Adélie (Australian and Antarctic conjugate margins). Terra Nova, 24, 167-180, doi: 10.1111/j.1365-3121.2011.01055.x.

Evans, N.G. 1993. Deformation during the Emplacement of the Maladeta Granodiorite, Spanish Pyrenees. PhD thesis, Univ. Leeds.

Evans, N.G., Gleizes, G., Leblanc, D. \& Bouchez, J.-L. 1997. Hercynian tectonics in the Pyrenees: a new view based on structural observations around the Bassie`s granite pluton. Journal of Structural Geology, 19, 195-208, doi: 10.1016/S0191-8141(96)00080-6.

FAbries, J., LoRAND, J.-P., Bodinier, J.-L. \& Dupuy, C. 1991. Evolution of the Upper Mantle beneath the Pyrenees: Evidence from Orogenic Spinel Lherzolite Massifs. Journal of Petrology, Special Volume, 55-76, doi: 10.1093/petrology/Special_Volume.2.55.

Fallourd, S., Poujol, M., Boulvais, P., Paquette, J.-L., Blanquat, M. De S. \& Rémy, P. 2014. In situ LA-ICP-MS U-Pb titanite dating of $\mathrm{Na}-\mathrm{Ca}$ metasomatism in orogenic belts: the North Pyrenean example. International Journal of Earth Sciences, 103, 667-682, doi: 10.1007/s00531-013-0978-1.

Fitzgerald, P.G., Muñoz, J.A., Coney, P.J. \& Baldwin, S.L. 1999. Asymmetric exhumation across the Pyrenean orogen: implications for the tectonic evolution of a collisional orogen. Earth and Planetary Science Letters, 173, 157-170, doi: 10.1016/S0012-821X(99)002253. 
Ford, M., Hemmer, L., VACherat, A., Gallagher, K. \& Christophoul, F. 2016. Retro-wedge foreland basin evolution along the ECORS line, eastern Pyrenees, France. Journal of the Geological Society, 173, 419-437, doi: 10.1144/jgs2015-129.

García SenZ, J. 2002. Cuencas extensivas del Cretácico Inferior en los Pirineos centrales. Formación y subsecuente inversión. PhD thesis, Univ. Barcelona, Spain.

GARCIA-SANSEGUNDO, J. 1992. Estratigrafía y estructura de la Zona Axial pirenaica en la transversal del Valle de Arán y de la Alta Ribagorça. Publicaciones especiales del Boletín Geológico y Minero, ITGE, 103, 1-290.

García-Sansegundo, J., Poblet, J., Alonso, J.L. \& Clariana, P. 2011. Hinterland-foreland zonation of the Variscan orogen in the Central Pyrenees: comparison with the northern part of the Iberian Variscan Massif. Geological Society, London, Special Publications, 349, 169-184, doi: 10.1144/SP349.9.

GLEIZES, G. 1992. Structure Des Granites Hercyniens Des Pyrénées de Mont-Louis-Andorre À La Maladeta. PhD thesis, Univ. Paul Sabatier,Toulouse, France.

Gleizes, G., Leblanc, D., SANTAna, V., Olivier, P. \& Bouchez, J.L. 1998. Sigmoidal structures featuring dextral shear during emplacement of the Hercynian granite complex of Cauterets-Panticosa (Pyrenees). Journal of Structural Geology, 20, 1229-1245, doi: 10.1016/S0191-8141(98)00060-1.

Gleizes, G., Leblanc, D. \& Bouchez, J.L. 1998. The main phase of the Hercynian orogeny in the Pyrenees is a dextral transpression. Geological Society, London, Special Publications, 135, 267-273, doi: 10.1144/GSL.SP.1998.135.01.17. 
GolberG, J.M. \& LeYRElOUP, A.F. 1990. High temperature-low pressure Cretaceous metamorphism related to crustal thinning (Eastern North Pyrenean Zone, France). Contributions to Mineralogy and Petrology, 104, 194-207, doi: 10.1007/BF00306443.

Gretter, N., Ronchi, A., López-Gómez, J., Arche, A., De la Horra, R., Barrenechea, J. \& Lago, M. 2015. The Late Palaeozoic-Early Mesozoic from the Catalan Pyrenees (Spain): $60 \mathrm{Myr}$ of environmental evolution in the frame of the western peri-Tethyan palaeogeography. Earth-Science Reviews, 150, 679-708, doi: 10.1016/j.earscirev.2015.09.001.

HARrison, T. M., DunCAN, I. \& MCDougall, I. 1985. Diffusion of ${ }^{40} \mathrm{Ar}$ in biotite: Temperature, pressure an compositional effects. Geochimica et Cosmochimica Acta, 49, 2461-2468, doi: $10.1016 / 0016-7037(85) 90246-7$.

HarteVelt, J.J.A. 1970. Geology of the Upper Segre and Valira valleys, Central Pyrenees, Andorra/Spain. Leidse Geologische Mededelingen, 45, 161-236.

HIRTH, G. \& TULLIS, J. 1992. Dislocation creep regimes in quartz aggregates. Journal of Structural Geology, 14, 145-159, doi: 10.1016/0191-8141(92)90053-Y.

IZQUiERdo-Llavall, E., CASAS-SAINZ, A.M. \& Oliva-URCiA, B. 2013. Heterogeneous deformation recorded by magnetic fabrics in the Pyrenean Axial Zone. Journal of Structural Geology, 57, 97-113, doi: 10.1016/j.jsg.2013.10.005.

Jolivet, M., Labaume, P., Monié, P., Brunel, M., Arnaud, N. \& Campani, M. 2007. Thermochronology constraints for the propagation sequence of the south Pyrenean basement thrust system (France-Spain). Tectonics, 26, TC5007, doi: 10.1029/2006TC002080. 
KRETZ, R. 1983. Symbols for rock-forming minerals. American Mineralogist, 68, 277-279.

LAGABRIELle, Y. \& BodinIER, J.-L. 2008. Submarine reworking of exhumed subcontinental mantle rocks: field evidence from the Lherz peridotites, French Pyrenees. Terra Nova, 20, 11-21, doi: 10.1111/j.1365-3121.2007.00781.x.

Lagabrielle, Y., Labaume, P. \& De Saint Blanquat, M. 2010. Mantle exhumation, crustal denudation, and gravity tectonics during Cretaceous rifting in the Pyrenean realm (SW Europe): Insights from the geological setting of the lherzolite bodies. Tectonics, 29, TC4012, doi: 10.1029/2009TC002588.

Lahfid, A., Beyssac, O., Deville, E., Negro, F., Chopin, C. \& Goffé, B. 2010. Evolution of the Raman spectrum of carbonaceous material in low-grade metasediments of the Glarus Alps (Switzerland). Terra Nova, 22, 354-360, doi: 10.1111/j.1365-3121.2010.00956.x.

LAUMONIER, B. 2015. Les Pyrénées alpines sud-orientales (France, Espagne) - essai de synthèse. Revue de Géologie Pyrénéenne, 2, 44 p. http://geologie-des-pyrenees.com/

LAUMONIER, B. (ED.). ET AL. 1996. Cambro-Ordovicien. In: Barnolas A., Chiron J.C.: 'Synthèse Géologique et Géophysique Des Pyrénées’. BRGM-ITGE, 157-209.

Le Pichon, X., Bonnin, J. \& Sibuet, J.-C. 1970. La faille nord-pyrénéenne : faille transformante liée à l'ouverture du golfe de gascogne. Comptes Rendus Académie des Sciences de Paris, 271, 1941-1944.

Losantos, M., Palau, J. \& SAnZ, J. 1986. Considerations about Hercynian thrusting in the Marimanya massif (central Pyrenees). Tectonophysics, 129, 71-79, doi: 10.1016/00401951(86)90246-5. 
LUCAS, C. 1985. Le grès rouge du versant nord des Pyrénées: essai sur la géodynamique de dépôts continentaux du Permien et du Trias. PhD, Univ. Paul Sabatier, Toulouse, France.

Majesté-Menjoulas, C. 1979. Evolution alpine d'un segment de chaîne varisque: Nappe de Gavarnie, chevauchement Cinq-Monts-Gentiane (Pyrénées centrales et occidentales). PhD, Univ. Paul Sabatier, Toulouse, France.

Majesté-Menjoulas, C., Debon, F., Driouch, Y., Flachere, H., Moreau, H., Valero, J. \& TERnet, Y. 1999. Carte Géologique de la France (1/50 000), Feuille Gavarnie (1082). BRGM, Orléans.

MartineZ-PeÑA, M. \& CASAS-SAINZ, A. 2003. Cretaceous-Tertiary tectonic inversion of the Cotiella Basin (southern Pyrenees, Spain). International Journal of Earth Sciences, 92, 99113, doi: 10.1007/s00531-002-0283-x.

Masini, E., Manatschal, G., Mohn, G., Ghienne, J.-F. \& Lafont, F. 2011. The tectonosedimentary evolution of a supra-detachment rift basin at a deep-water magma-poor rifted margin: the example of the Samedan Basin preserved in the Err nappe in SE Switzerland. Basin Research, 23, 652-677, doi: 10.1111/j.1365-2117.2011.00509.x.

Masini, E., Manatschal, G., Tugend, J., Mohn, G. \& Flament, J.-M. 2014. The tectonosedimentary evolution of a hyper-extended rift basin: the example of the Arzacq-Mauléon rift system (Western Pyrenees, SW France). International Journal of Earth Sciences, 103, 1569-1596, doi: 10.1007/s00531-014-1023-8.

MAtTE, P., 2001. The Variscan collage and orogeny (480-290Ma) and the tectonic definition of the Armorica microplate: a review. Terra Nova, 13, 122-128, doi: 10.1046/j.13653121.2001.00327.x. 
830 Maurel, O., Monié, P., Pik, R., Arnaud, N., Brunel, M. \& Jolivet, M. 2008. The Meso-

831 Cenozoic thermo-tectonic evolution of the Eastern Pyrenees: an ${ }^{40} \mathrm{Ar} /{ }^{39} \mathrm{Ar}$ fission track and 832 (U-Th)/He thermochronological study of the Canigou and Mont-Louis massifs. 833 International Journal of Earth Sciences, 97, 565-584, doi: 10.1007/s00531-007-0179-x.

834 McCAIG, A. 1986. Thick- and thin-skinned tectonics in the Pyrenees. Tectonophysics, 129, 319835 342, doi: 10.1016/0040-1951(86)90259-3.

836

MCCAiG, A. \& Miller, J.A. 1986. ${ }^{40} \mathrm{Ar} /{ }^{39} \mathrm{Ar}$ age of mylonites along the Mérens fault, Central 837 Pyrenees. Tectonophysics, 129, 149-172, doi: 10.1016/0040-1951(86)90250-7.

838

840

McIntosh, K., Avendonk, H. VAN, ET AL. 2013. Inversion of a hyper-extended rifted margin in the southern Central Range of Taiwan. Geology, 41, 871-874, doi: 10.1130/G34402.1.

841

842

843

MENCOS, J., CARRERA, N. \& MUÑOZ, J.A. 2015. Influence of rift basin geometry on the subsequent postrift sedimentation and basin inversion: The Organyà Basin and the Bóixols thrust sheet (south central Pyrenees). Tectonics, 34, 2014TC003692, doi: 10.1002/2014TC003692.

Mesalles, L., Mouthereau, F., Bernet, M., Chang, C.-P., Lin, A.T.-S., Fillon, C. \& SEngELEN, X. 2014. From submarine continental accretion to arc-continent orogenic evolution: The thermal record in southern Taiwan. Geology, 42, 907-910, doi: 10.1130/G35854.1.

MetCalf, J.R., Fitzgerald, P.G., Baldwin, S.L. \& MuÑOZ, J.-A. 2009. Thermochronology of a convergent orogen: Constraints on the timing of thrust faulting and subsequent exhumation of the Maladeta Pluton in the Central Pyrenean Axial Zone. Earth and Planetary Science Letters, 287, 488-503, doi: 10.1016/j.eps1.2009.08.036. 
852 MeY, P.H.W. 1968. The geology of the upper Ribagorzana and Tor Valleys, Central Pyrenees, Spain sheet 8, 1: 50000. Leidse Geologische Mededelingen, 41, 229-292.

854

MezGER, J.E. 2005. Comparison of the western Aston-Hospitalet and the Bossòst domes: Evidence for polymetamorphism and its implications for the Variscan tectonic evolution of the Axial Zone of the Pyrenees. Journal of the Virtual Explorer, 19, doi: 10.3809/jvirtex.2005.00122.

MEZGER, J.E. 2009. Transpressional tectonic setting during the main Variscan deformation: evidence from four structural levels in the Bossòst and Aston-Hospitalet mantled gneiss domes, central Axial Zone, Pyrenees. Bulletin de la Société Géologique de France, 180, 199-207, doi: 10.2113/gssgfbull.180.3.199.

MEZGER, J.E. \& PASSCHIER, C.W. 2003. Polymetamorphism and ductile deformation of staurolitecordierite schist of the Bossòst dome: indication for Variscan extension in the Axial Zone of the central Pyrenees. Geological Magazine, 140, 595-612, doi: 10.1017/S0016756803008112.

MezGer, J.E. \& Regnier, J.-L. 2016. Stable staurolite-cordierite assemblages in K-poor metapelitic schists in Aston and Hospitalet gneiss domes of the central Pyrenees (France, Andorra). Journal of Metamorphic Geology, 34, 167-190, doi: 10.1111/jmg.12177.

Mirouse, R., BArrère, P., ET AL. 1993. Carte Géol. France (1/50 000), Feuille Vielle-Aure (1083). BRGM, Orléans.

Mohn, G., Manatschal, G., Beltrando, M., Masini, E. \& Kusznir, N. 2012. Necking of continental crust in magma-poor rifted margins: Evidence from the fossil Alpine Tethys margins. Tectonics, 31, TC1012, doi: 10.1029/2011TC002961. 
873 MoniÉ, P., Soliva, J., Brunel, M. \& Maluski, H. 1994. Les cisaillements mylonitiques du

874

875

876

877

878

879

880

881

882

883

884

885

886

887

888

889

890

891

892

893

894 granite de Millas (Pyrénées, France). Age Crétacé ${ }^{40} \mathrm{Ar} /{ }^{39} \mathrm{Ar}$ et interprétation tectonique. Bulletin de la Société Géologique de France, 165, 559-571.

Mouthereau, F. \& Lacombe, O. 2006. Inversion of the Paleogene Chinese continental margin and thick-skinned deformation in the Western Foreland of Taiwan. Journal of Structural Geology, 28, 1977-1993, doi: 10.1016/j.jsg.2006.08.007.

Mouthereau, F., Lacombe, O. \& Vergés, J. 2012. Building the Zagros collisional orogen: Timing, strain distribution and the dynamics of Arabia/Eurasia plate convergence. Tectonophysics, 532-535, 27-60, doi: 10.1016/j.tecto.2012.01.022.

Mouthereau, F., WatTs, A.B. \& Burov, E. 2013. Structure of orogenic belts controlled by lithosphere age. Nature Geoscience, 6, 785-789, doi: 10.1038/ngeo1902.

Mouthereau, F., Filleaudeau, P.-Y., ET AL. 2014. Placing limits to shortening evolution in the Pyrenees: Role of margin architecture and implications for the Iberia/Europe convergence. Tectonics, 33, 2014TC003663, doi: 10.1002/2014TC003663.

MuÑOZ, J.A. 1992. Evolution of a continental collision belt: ECORS-Pyrenees crustal balanced cross-section. In: Thrust Tectonics, edited by K.R. McClay, 235-246, Chapman \& Hall, London, doi: 10.1007/978-94-011-3066-0_21.

Olivet, J.-L. 1996. La cinématique de la plaque ibérique. Bulletin des Centres de Recherches Exploration Production Elf-Aquitaine, 20, 131-195.

Paquette, J.-L., Gleizes, G., Leblanc, D. \& Bouchez, J.-L. 1997. Le granite de Bassiès (Pyrénées) : un pluton syntectonique d'âge Westphalien. Géochronologie U-Pb sur zircons. Comptes Rendus de l'Académie des Sciences, Paris, 324, 387-392. 
895

896

897

898

899

900

901

902

903

904

905

906

907

908

909

910

911

912

913

914

915

Peron-Pinvidic, G., Manatschal, G. \& Osmundsen, P.T. 2013. Structural comparison of archetypal Atlantic rifted margins: A review of observations and concepts. Marine and Petroleum Geology, 43, 21-47, doi: 10.1016/j.marpetgeo.2013.02.002.

Poujol, M., Boulvais, P. \& Kosler, J. 2010. Regional-scale Cretaceous albitization in the Pyrenees: evidence from in situ $\mathrm{U}-\mathrm{Th}-\mathrm{Pb}$ dating of monazite, titanite and zircon. Journal of the Geological Society, 167, 751-767, doi: 10.1144/0016-76492009-144.

RANero, C.R. \& PÉREZ-GussinYÉ, M. 2010. Sequential faulting explains the asymmetry and extension discrepancy of conjugate margins. Nature, 468, 294-299, doi: 10.1038/nature09520.

Roca, E., Muñoz, J.A., Ferrer, O. \& Ellouz, N. 2011. The role of the Bay of Biscay Mesozoic extensional structure in the configuration of the Pyrenean orogen: Constraints from the MARCONI deep seismic reflection survey. Tectonics, 30, TC2001, doi: 10.1029/2010TC002735.

Roest, W.R. \& SRIVASTAVA, S.P. 1991. Kinematics of the plate boundaries between Eurasia, Iberia, and Africa in the North Atlantic from the Late Cretaceous to the present. Geology, 19, 613-616, doi: 10.1130/0091-7613(1991)019<0613:KOTPBB>2.3.CO;2.

Roure, F., ChOUKRoune, P., ET AL. 1989. ECORS deep seismic data and balanced cross sections: Geometric constraints on the evolution of the Pyrenees. Tectonics, 8, 41-50.

Schärer, De Parseval, Polvé \& De Saint Blanquat. 1999. Formation of the Trimouns talcchlorite deposit (Pyrenees) from persistent hydrothermal activity between 112 and 97 Ma. Terra Nova, 11, 30-37, doi: 10.1046/j.1365-3121.1999.00224.x. 
916

917

918

919

920

921

922

923

924

925

926

927

928

929

930

931

932

933

934

935

936

937

SÉGURET, M. 1972. Etude tectonique des nappes et séries décollées de la partie centrale du versant sud des Pyrénées : caractère synsédimentaire, rôle de la compression et de la gravité. $\mathrm{PhD}$ thesis, Univ. Montpellier, France.

Sibuet, J.-C., SRIVAStaVA, S.P. \& Spakman, W. 2004. Pyrenean orogeny and plate kinematics. Journal of Geophysical Research: Solid Earth, 109, B08104, doi: 10.1029/2003JB002514.

Sinclair, H.D., Gibson, M., NAYlor, M. \& Morris, R.G. 2005. Asymmetric growth of the Pyrenees revealed through measurement and modeling of orogenic fluxes. American Journal of Science, 305, 369-406, doi: 10.2475/ajs.305.5.369.

Soler, D., TeIXell, A. \& GarcíA-SAnsegundo, J. 1998. Amortissement latéral du chevauchement de Gavarnie et sa relation avec les unités sud-pyrénéennes. Comptes Rendus de l'Académie des Sciences, Paris, 327, 699-704, doi: 10.1016/S12518050(99)80028-7.

SONG, W.J. \& REE, J.-H. 2007. Effect of mica on the grain size of dynamically recrystallized quartz in a quartz-muscovite mylonite. Journal of Structural Geology, 29, 1872-1881, doi: 10.1016/j.jsg.2007.09.011.

Soulaimani, A. \& Burkhard, M. 2008. The Anti-Atlas chain (Morocco): the southern margin of the Variscan belt along the edge of the West African craton. Geological Society, London, Special Publications, 297, 433-452, doi: 10.1144/SP297.20.

StAmpfli, G.M., Hochard, C., VÉRARd, C., Wilhem, C., VONRAUMER, J. 2013. The formation of Pangea. Tectonophysics, 593, 1-19, doi: 10.1016/j.tecto.2013.02.037.

StiPP, M., StÜNITZ, H., HeILbROnNeR, R. \& SCHMID, S.M. 2002. The eastern Tonale fault zone: a 'natural laboratory' for crystal plastic deformation of quartz over a temperature range 
from 250 to $700{ }^{\circ}$ C. Journal of Structural Geology, 24, 1861-1884, doi: 10.1016/S01918141(02)00035-4.

Sutra, E., Manatschal, G., Mohn, G. \& Unternehr, P. 2013. Quantification and restoration of extensional deformation along the Western Iberia and Newfoundland rifted margins. Geochemistry, Geophysics, Geosystems, 14, 2575-2597, doi: 10.1002/ggge.20135.

TeiXell, A. 1996. The Ansó transect of the southern Pyrenees: basement and cover thrust geometries. Journal of the Geological Society, 153, 301-310, doi: 10.1144/gsjgs.153.2.0301.

Ternet, Y., BARrère, P., ET AL. 1980. Carte Géologique de la France (1/50 000), Feuille Argelès-Gazost (1070), BRGM. BRGM, Orléans.

Ternet, Y., Colchen, M., Et AL. 1997. Notice Explicative, Carte Géol. France (1/50 000), Feuille Aulus-Les-Bains (1086), BRGM, Orléans.

Ternet, Y., Barrère, P., Canerot, J. \& Majeste-Menjoulas, C. 2003. Carte Géologique de la France (1/50 000), Feuille Laruns-Somport (1069). BRGM, Orléans.

Triboulet, C., Guitard, G., KAtona, I. \& NAvidad, M. 2005. Évolution pression-température des amphibolites de la zone axiale au cours du métamorphisme hercynien des Pyrénées orientales. Comptes Rendus Geoscience, 337, 1244-1249, doi: 10.1016/j.crte.2005.06.011.

Tugend, J., Manatschal, G., Kusznir, N.J., Masini, E., Mohn, G. \& Thinon, I. 2014. Formation and deformation of hyperextended rift systems: Insights from rift domain mapping in the Bay of Biscay-Pyrenees. Tectonics, 33, 2014TC003529, doi: 10.1002/2014TC003529. 
959

960

961

962

963

964

965

966

967

968

969

970

971

972

973

974

975

976

977

978

979

980

Vacherat, A., Mouthereau, Pik, R., Bernet, M., Gautheron, C., Masini, E., Le Pourhiet, L., TIBARI, B., LAHFID, A. 2014. Thermal imprint of rift-related processes in orogens as recorded in the Pyrenees. Earth and Planetary Science Letters, 408, 296-306, doi: 10.1016/j.epsl.2014.10.014.

Vacherat, A., Mouthereau, F., Pik, R., Bellahsen, N., Gautheron, C., Bernet, M., Daudet, M., Balansa, J., Tibari, B., Jamme, R. P., Radal, J. 2016. Rift-to-collision transition recorded by tectonothermal evolution of the northern Pyrenees. Tectonics, 35, 2015TC004016, doi: 10.1002/2015TC004016.

Vauchez, A., Clerc, C., Bestani, L., Lagabrielle, Y., Chauvet, A., Lahfid, A. \& MAINPRICE, D. 2013. Preorogenic exhumation of the North Pyrenean Agly massif (Eastern Pyrenees-France). Tectonics, 32, 95-106, doi: 10.1002/tect.20015.

Vergely, P. 1970. Étude tectonique des structures pyrénéennes du versant sud des Pyrénées Orientales entre le rio Lliobregat et le rio Ter, province de Barcelone et de Gerone, Espagne. PhD thesis, Univ. Montpellier, France.

Vergés, J., MiLlan, H., ET AL. 1995. Eastern Pyrenees and related foreland basins: pre-, syn- and post-collisional crustal-scale cross-sections. Marine and Petroleum Geology, 12, 903-915, doi: 10.1016/0264-8172(95)98854-X.

Vergés, J., Fernàndez, M. \& Martínez, A. 2002. The Pyrenean orogen: pre-, syn-, and postcollisional evolution. Journal of the Virtual Explorer, 8, 55-74.

Vielzeuf, D. \& Kornprobst, J. 1984. Crustal splitting and the emplacement of Pyrenean lherzolites and granulites. Earth and Planetary Science Letters, 67, 87-96, doi: $10.1016 / 0012-821 X(84) 90041-4$. 
981 Vilà, M., Pin, C., LiesA, M. \& EnRiQue, P. 2007. LPHT metamorphism in a late orogenic

982

983

984

985

986

987

988

989

990

991

992

993

994

995

996

997

998

999

1000

1001

1002

1003 transpressional setting, Albera Massif, NE Iberia: implications for the geodynamic evolution of the Variscan Pyrenees. Journal of Metamorphic Geology, 25, 321-347, doi: 10.1111/j.1525-1314.2007.00698.x.

VisSERS, R.L.M. \& MEIJER, P.T. 2012. Iberian plate kinematics and Alpine collision in the Pyrenees. Earth-Science Reviews, 114, 61-83, doi: 10.1016/j.earscirev.2012.05.001.

Vissers, R.L.M. van Hinsbergen, D.J.J., Wilkinson, C.M. \& GanerøD, M. 2017. Middle Jurassic shear zones at Cap de Creus (eastern Pyrenees, Spain): a record of pre-drift extension of the Piemonte-Ligurian Ocean? Journal of the Geological Society, 174, 289-300, doi:10.1144/jgs2016-014

WAYNe, D. M. \& MCCAIG, A. M. 1998. Dating fluid flow in shear zones: Rb-Sr and U-Pb studies of syntectonic veins in the Néouvielle Massif, Pyrenees. Geological Society, London, Special Publications, 144, 129-135, doi: 10.1144/GSL.SP.1998.144.01.09.

Wrobel-Daveau, J.-C., Ringenbach, J.-C., Tavakoli, S., Ruiz, G.M.H., Masse, P. \& LAMOTTE, D.F. DE. 2010. Evidence for mantle exhumation along the Arabian margin in the Zagros (Kermanshah area, Iran). Arabian Journal of Geosciences, 3, 499-513, doi: 10.1007/s12517-010-0209-z.

Wu, J.E., McClay, K., Whitehouse, P. \& Dooley, T. 2009. 4D analogue modelling of transtensional pull-apart basins. Marine and Petroleum Geology, 26, 1608-1623, doi: 10.1016/j.marpetgeo.2008.06.007.

ZAndVliet, J. 1960. The geology of the upper Salat and Pallaresa valleys, Central Pyrenees, France/Spain. Leidse Geologische Mededelingen, 25, 1-127. 
1004

1005

1006

1007

1008

1009

1010

1011

1012

1013

1014

1015

1016

1017

1018

1019

1020

1021

1022

1023

1024

1025

1026

1027

Zwart, H.J. 1979. The geology of the Central Pyrenees. Leidse Geologische Mededelingen, 50, 1-74.

ZWART, H.J. 1986. The Variscan geology of the Pyrenees. Tectonophysics, 129, 9-27.

Zwart, H.J., Roberti, K.F., ET AL. 1976. Geological Map of the Central Pyrenees. Sheet 9. Flamisell-Pallaresa (Spain). Scale 1/50,000. Geological Institute, University of Leiden.

\section{Figure captions:}

Figure 1: (a) Location of the Variscan crust of the Pyrenees in western Europe, with main Mesozoic basins. 1- Organyà basin, 2- Arzacq-Mauléon basin, 3- Parentis basin, 4- BascoCantabrian and le Danois basins, 5- Central Iberian basins (Tugend et al., 2014); (b) Geological sketch map of the Variscan crust of the Pyrenees. In blue: main Alpine faults; in black: main Variscan shear zones. Abbreviations: ELT: Les Eaux Chaudes/Lakhora Thrust; GT: Gavarnie Thrust; NPF: North Pyrenean Fault, LT: Llavorsi thrust, MSZ: Mérens Shear Zone). (c) Tectonic subdivision of the Axial Zone (Mouthereau et al. 2014).

Figure 2: Geological map of the Central Pyrenees, modified from Colchen et al. (1995) and Zwart et al. (1976) showing location of the Pallaresa cross-section presented in this work (Fig. 4). Studied outcrop and samples for RSCM measurements are also reported.

Figure 3: (a) Structural map of the Central Pyrenees. In grey: Upper Paleozoic rocks; in white: Cambrian to Ordovician rocks; in orange and pink: Variscan domes and granitoids, respectively. In blue: stretching lineations and kinematics from Evans et al. (1997). Data compiled for cleavage trajectories are from Mey (1968), Hartevelt (1970), Colchen et al. (1995), Evans et al. (1997), 
1028 Mezger (2005) (Aston metamorphic dome), and from our observations $(\mathrm{n}=300)$. Foliation

1029 trajectories in plutons were deduced from AMS studies by Gleizes (1992), Evans et al. (1997) and

1030 Antolín-Tomás et al. (2009). (b) S1 (black) and Sa (blue) schistosity poles from our measurements.

1031 (c) L1 mineral-stretching lineations measured in the field in black, and Fa fold axes in blue.

1032 Stereograms: lower hemisphere, equal area projection. Contours at $2 \sigma$ are calculated for black 1033 points (i.e. S1 and L1).

1034

1035 Figure 4: N-S geological cross-section of the Central Pyrenees. Only significant alpine corridors 1036 that have been observed or rigorously described in the litterature are represented on this cross1037 section

1038

1039 Figure 5: Field photographs illustrating the mains structures described in the text. (a) Undeformed 1040 Lower to Middle Triassic sandstones and conglomerates; bedding is sub-horizontal and 1041 sedimentary figures attest normal polarity (Location: Port del Canto, Rubiò); Photograph (b) and 1042 interpretative sketch (b') of penetrative axial-plane cleavage in siltites and sandstones (Location: 1043 South of Alós d'Isil); (c) Asymmetrical boudinated sandstones in marbles of the Lladorre shear 1044 zone, showing north-side-up kinematics ; (d) C' shears with top-to-the-south kinematics in Upper 1045 Ordovician conglomerates (Location: Cardós valley).

1047 Figure 6: (a) Asymetrical boudinated quartz veins within Cambro-Ordovician sandstones showing 1048 dextral kinematics (Location: south of the Port de Marterat, western part of the country-rocks of 1049 the Bassiès pluton); (b) Apparent obliquity between the regional schistosity S0-1 and the late 1050 crenulation cleavage associated to kink-bands (Same location than Fig. 6a \& 6b); (c) Longitudinal 1051 late folds and associated crenulation cleavage Sa steeply dipping to the south and affecting the 1052 regional schistosity S0-1 (Location: 400m north of Ainet de Cardós). 
1054 Figure 7: (a) Palaeotemperatures obtained by Raman Spectroscopy of Carbonaceous Material

1055 (RSCM). Error bars are standard deviation. X-axis corresponds to the latitude; (b) Interpreted 1056 position of isotherms in our cross-section deduced from RSCM data and petrological descriptions.

1058 Figure 8: Microphotographs of various rocks of the Pallaresa. Bt: biotite, Ms: muscovite, Chl:

1059 chlorite. Explanations are in the text. (a) Precambrian schist of the Palarressa anticline (sample

1060 15BL106). (b) Microphotograph of a muscovite-bearing schist. Schistosity, underlined by

1061 muscovite, with dip around $30^{\circ}$ to the north and inflected by a "top-to-the-south" C' shear band.

1062 (c and d) Quartz pebble of the Upper Ordovician conglomerate showing dynamic recrystallization:

1063 bugling in (c) and sub-grain rotation in (d). (e) Chlorite-bearing schist of the Orri anticline. Sa:

1064 Steep alpine cleavage, S1: main schistosity (S1).

1065

1066 Figure 9: Tectonic evolution of the Axial Zone. Further explanations are in the text.

1067

1068 Figure 10: (a) 3D bloc-diagram of the Cretaceous transcurrent rifting mode in the Pyrenees ; (b)

1069 3D bloc-diagram showing the lithospheric architecture of the Central Pyrenean belt. Interpretation

1070 of deep structures from Choukroune (1989) and Muñoz (1992), except in the Axial Zone. Massifs

1071 with apatite fission-track data in the Central Pyrenees are represented. In brown, the Nogueres

1072 cover nappes; (c) Apatite fission-track ages obtained in the Central Axial Zone by Fitzgerald et al.

1073 (1999), Sinclair et al. (2005), and Metcalf et al. (2009), plotted together in an age-elevation plot. 


\section{Fityltentic ocear}

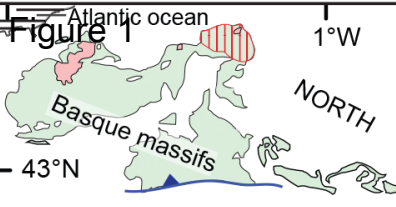

ـ Alpine thrust

\section{$50 \mathrm{~km}$}

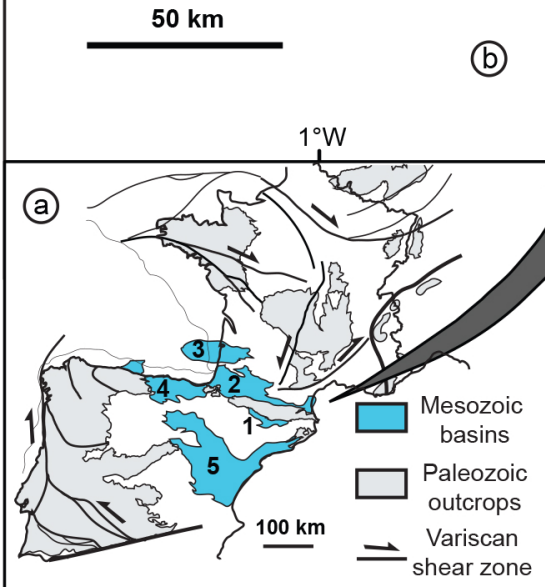

$1^{\circ} \mathrm{E}$ Click here to dowalead Figure Figure_13

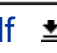

Cambrian to Ordovician plutons

미 HT/LP metamorphic domes

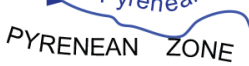

$\square$ Paleozoic sedimentary rocks

North Pyrenean Massifs

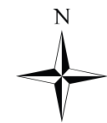

\section{Axial Zone $(\mathrm{sh})$}

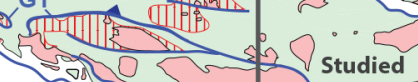
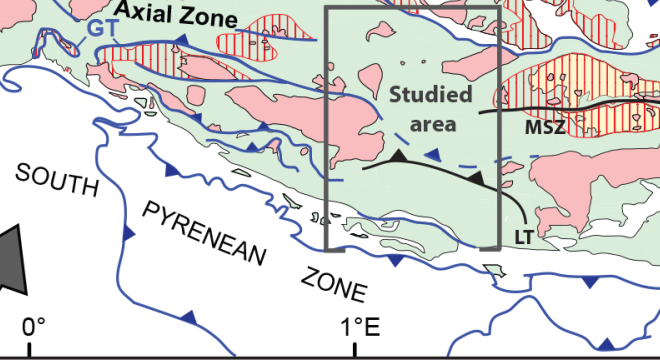<smiles>C1=CCCCCCCCCCCC1</smiles>

NPF

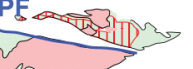<smiles>c1ccccc1</smiles>

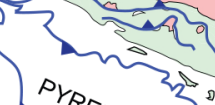
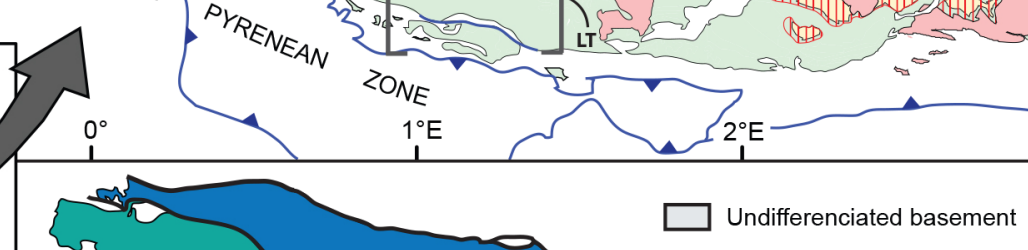

(C)

c)

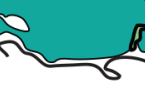

Lakhora unit

Gavarnie/Nogueres unit

Bielsa/Orri unit

Rialp unit
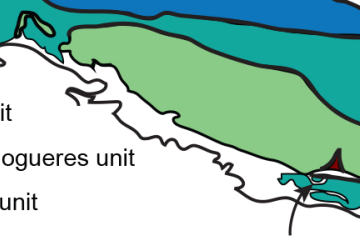

«Plunging noses» 


\section{Figure 2}

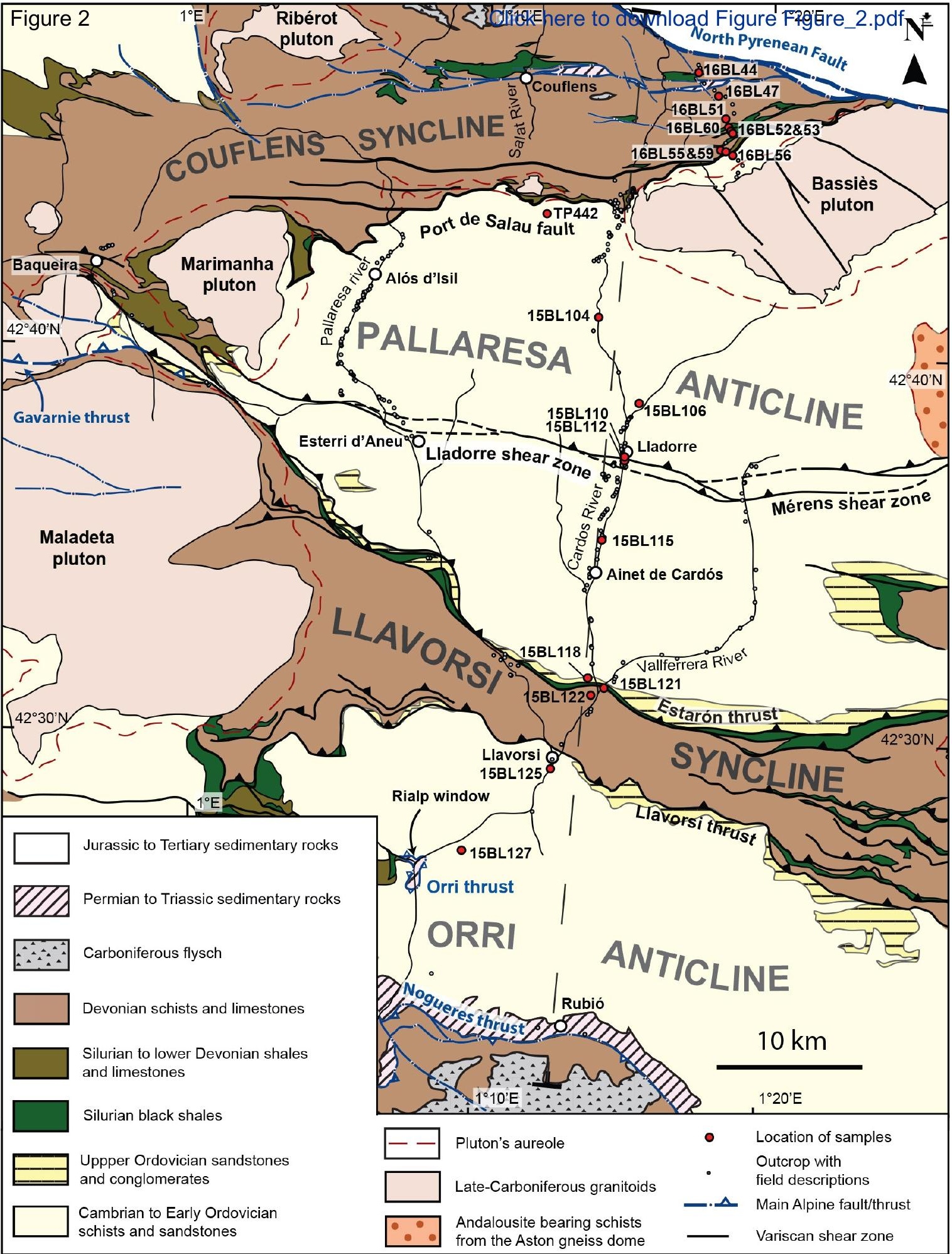

Cochelin et al., Figure 2 
Clickshere to download Figure Figur ${ }^{3} \theta^{3} \mathrm{kdf}$
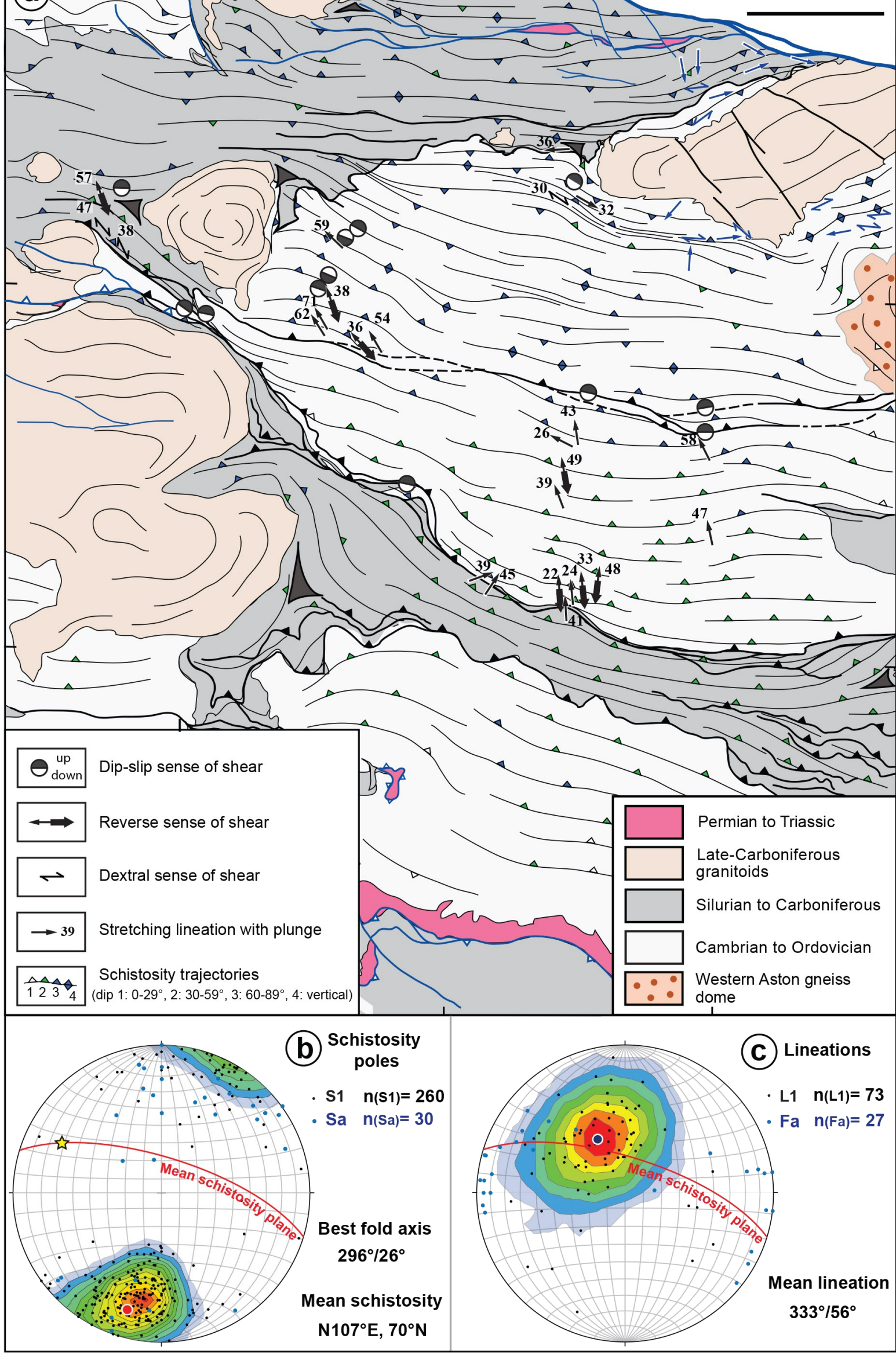

Cochelin et al., Figure 3 


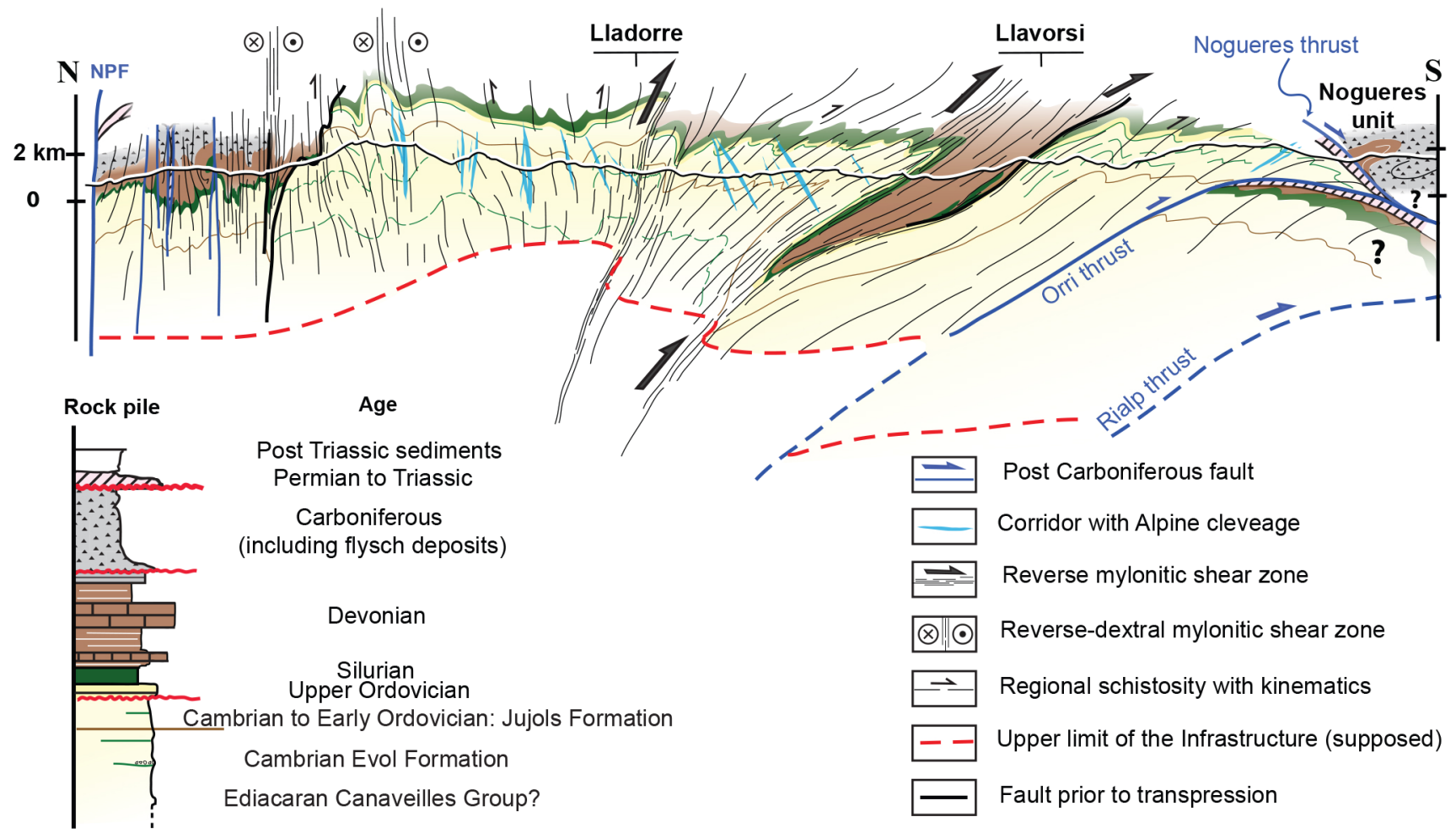




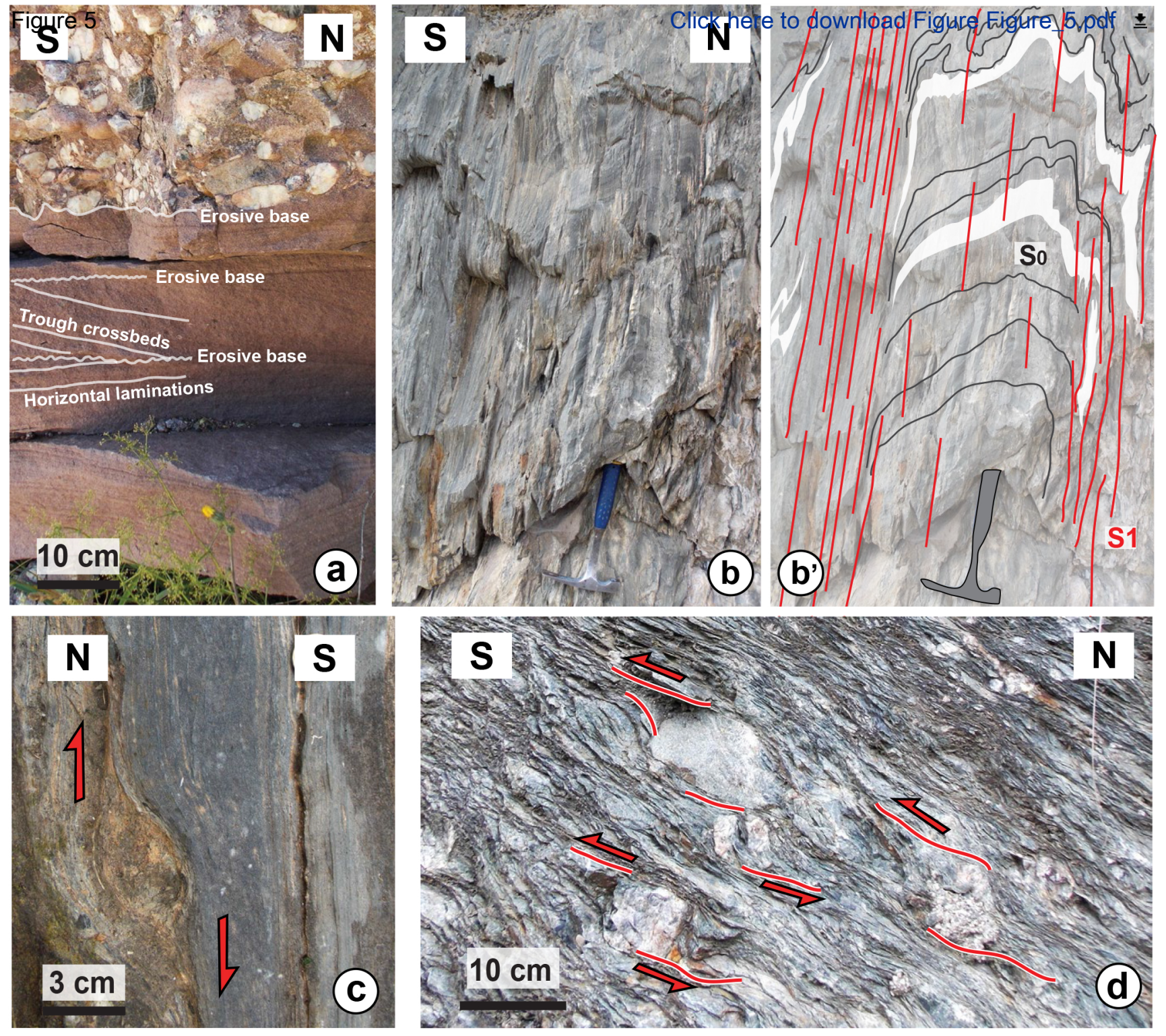

Cochelin et al., Figure 5 

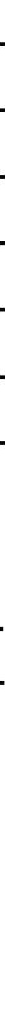

Cochelin et al., Figure 7 


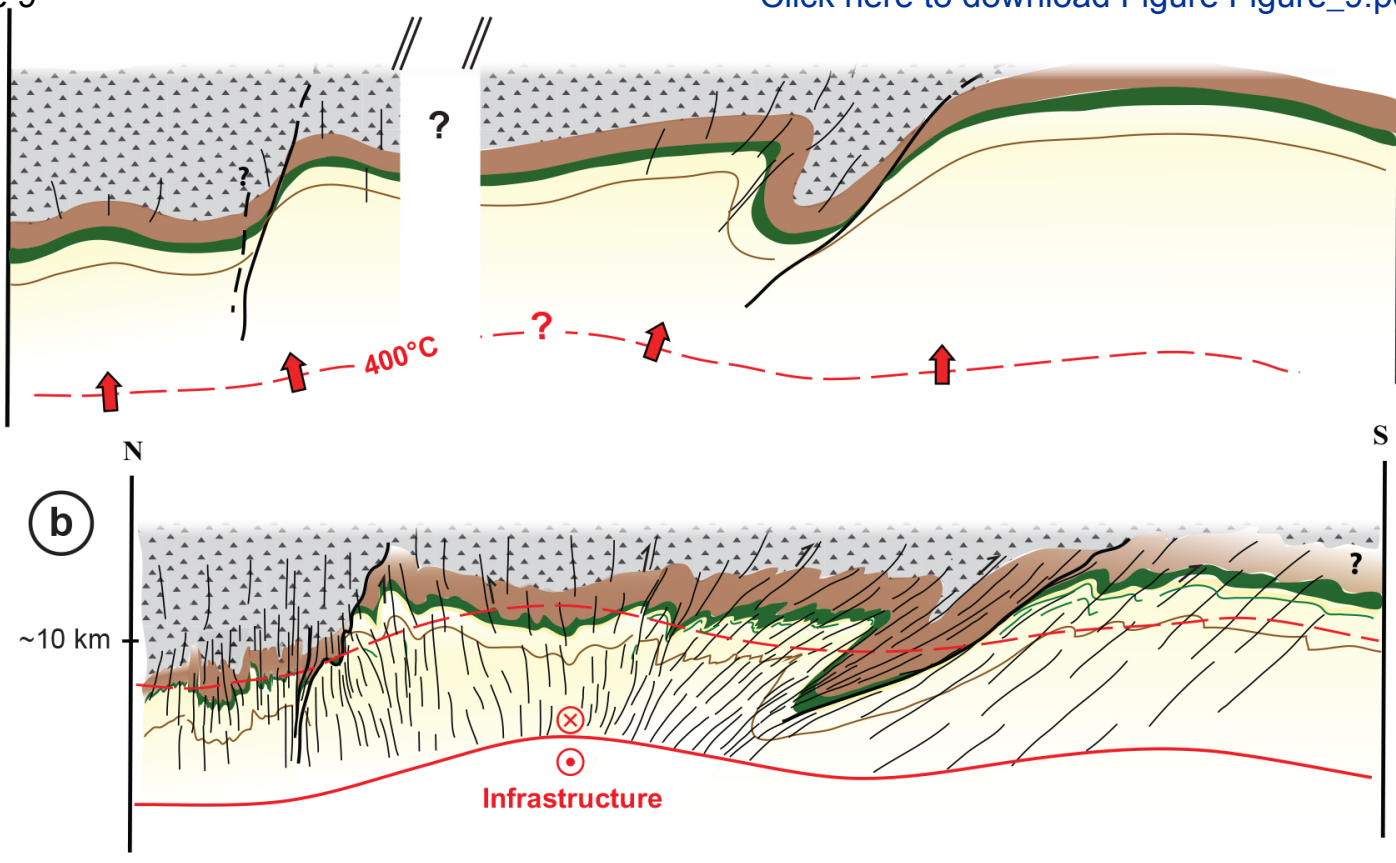

(c)

(d) Aston dome
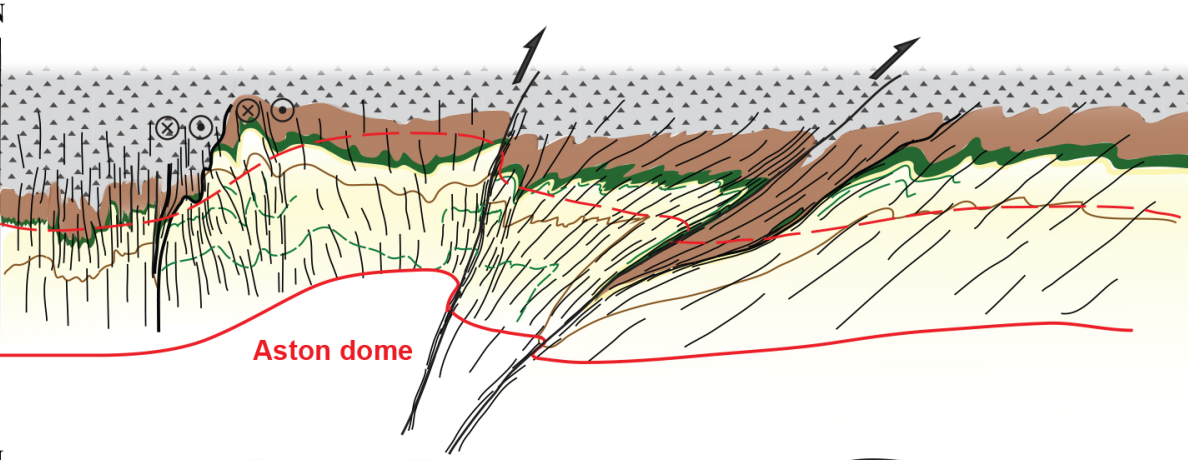

(e) NPFy

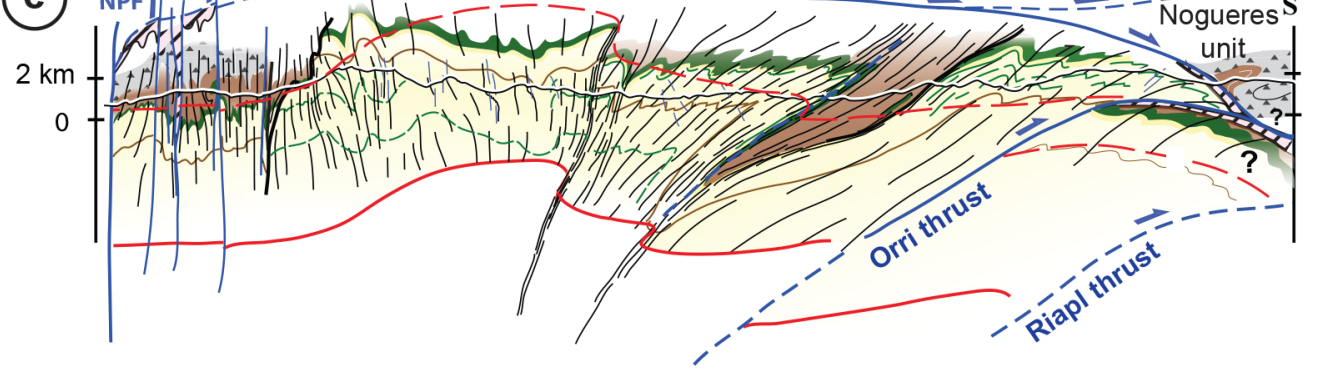

Cochelin et al., Figure 9 


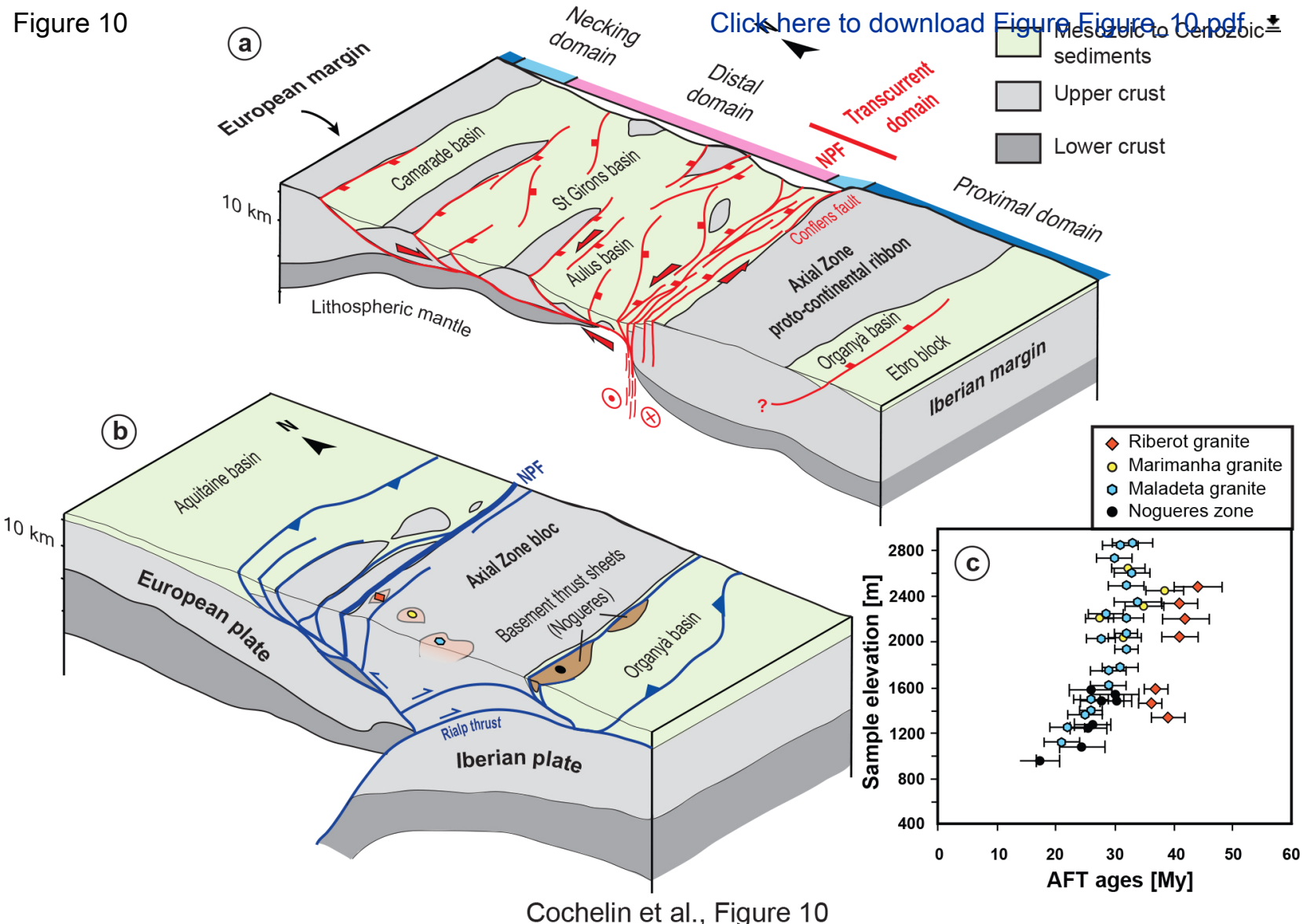

